\title{
Detrital zircon provenance of Mesoproterozoic to Cambrian arenites in the western United States and northwestern Mexico
}

\author{
John H. Stewart* \\ U.S. Geological Survey, 345 Middlefield Road, Menlo Park, California 94025, USA
}

George E. Gehrels

Department of Geosciences, University of Arizona, Tucson, Arizona 85721, USA

Andrew P. Barth

Department of Geology, Indiana/Purdue University, Indianapolis, Indiana 46202, USA

Paul K. Link

Department of Geology, Idaho State University, Pocatello, Idaho 83209, USA

Nicholas Christie-Blick

Lamont-Doherty Earth Observatory, Columbia University, Palisades, New York 10964, USA

Chester T. Wrucke

U.S. Geological Survey, 345 Middlefield Road, Menlo Park, California 94025, USA

\section{ABSTRACT}

U-Pb isotopic dating of detrital zircon from supracrustal Proterozoic and Cambrian arenites from the western United States and northern Mexico reveal three main age groups, 1.90 to $1.62 \mathrm{Ga}, 1.45$ to $1.40 \mathrm{Ga}$, and 1.2 to $1.0 \mathrm{Ga}$. Small amounts of zircons with ages of 3.1 to $2.5 \mathrm{Ga}, \mathbf{1 . 5 7}$ Ga, 1.32 Ga, 1.26 Ga, 0.7 Ga, and 0.5 Ga are also present.

Detrital zircons ranging in age from 1.90 to $1.62 \mathrm{Ga}$ and from 1.45 to $1.40 \mathrm{Ga}$ are considered to have been derived from Proterozoic crystalline basement rocks of these known ages, and probably in part from reworked Proterozoic supracrustal sedimentary rocks, of the western United States. The 1.2 to 1.0 Ga detrital zircon ages from California, Arizona, and Sonora are characterized by distinct spikes (1.11 Ga, in particular) in the age-probability plots. These spikes are interpreted to indicate the influx of zircon from major silicic volcanic fields. Igneous rocks such as the Pikes Peak Granite (1.093 Ga) of Colorado, and the Aibo Granite (1.110 Ga) of Sonora, Mexico, may represent the deeply eroded roots of such volcanic fields. Samples from farther north along the Cordilleran margin that

\footnotetext{
*E-mail: stewart@usgs.gov.
}

contain abundant 1.2-1.0 Ga detrital zircons do not show spikes in the age distribution, but rather ages spread out across the entire 1.2-1.0 Ga range. These age spectra resemble those for detrital zircons from the Grenville province, which is considered their source.

Less common detrital zircons had a variety of sources. Zircons ranging in age from 3.36 to $2.31 \mathrm{Ga}$ were apparently derived from inland parts of the North American continent from Wyoming to Canada. Zircons of about $1.577 \mathrm{Ga}$ are highly unusual and may have had an exotic source; they may have come from Australia and been deposited in North America when Australia and North America were juxtaposed as part of the hypothetical Rodinian supercontinent. Detrital zircon of $\sim \mathbf{1 . 3 2 0}$ Ga apparently had the same source as that for tuff $(1.320 \mathrm{Ga})$ in the Pioneer Shale of the Apache Group in Arizona. Detrital zircons of about 1.26 Ga in the Apache Group and Troy Quartzite appear to be related to local, approximately coeval volcanic fields. Zircons of about 0.7 Ga may have had a source in igneous rocks related to rifting of the Proterozoic supercontinent of Rodinia, and 0.5 Ga zircons a source in relatively small areas of granitic rocks of this known, or inferred, age in Oklahoma, Texas, New Mexico, and Colorado.
Keywords: Cambrian, geochronology, Mexico, Proterozoic, United States, zircon.

\section{INTRODUCTION}

The source of voluminous arenite in supracrustal Mesoproterozoic to Middle Cambrian strata in the western United States and northern Mexico is critical in understanding the sedimentary and tectonic history of the Proterozoic and Cambrian continental margin of North America. The ages of detrital zircons in these arenites provide information for locating the source areas, for understanding the amount of mixing from multiple sources, and for determining sedimentary dispersal patterns. Our study also reveals the igneous and tectonic setting of the source areas, information that has largely been destroyed by deep erosion of cratonal areas of North America. Detrital zircon data also provide information on the maximum age and possible correlations of sedimentary units.

This study consists of data from 11 newly studied localities and integrates this information with data from five previously studied localities (Gehrels and Dickinson, 1995; Gehrels and Stewart, 1998; Gross et al., 2000) (Fig. 1; Table 1; geochronologic data on the zircons

GSA Bulletin; October 2001; v. 113; no. 10; p. 1343-1356; 7 figures; 2 tables; Data Repository item 2001110. 


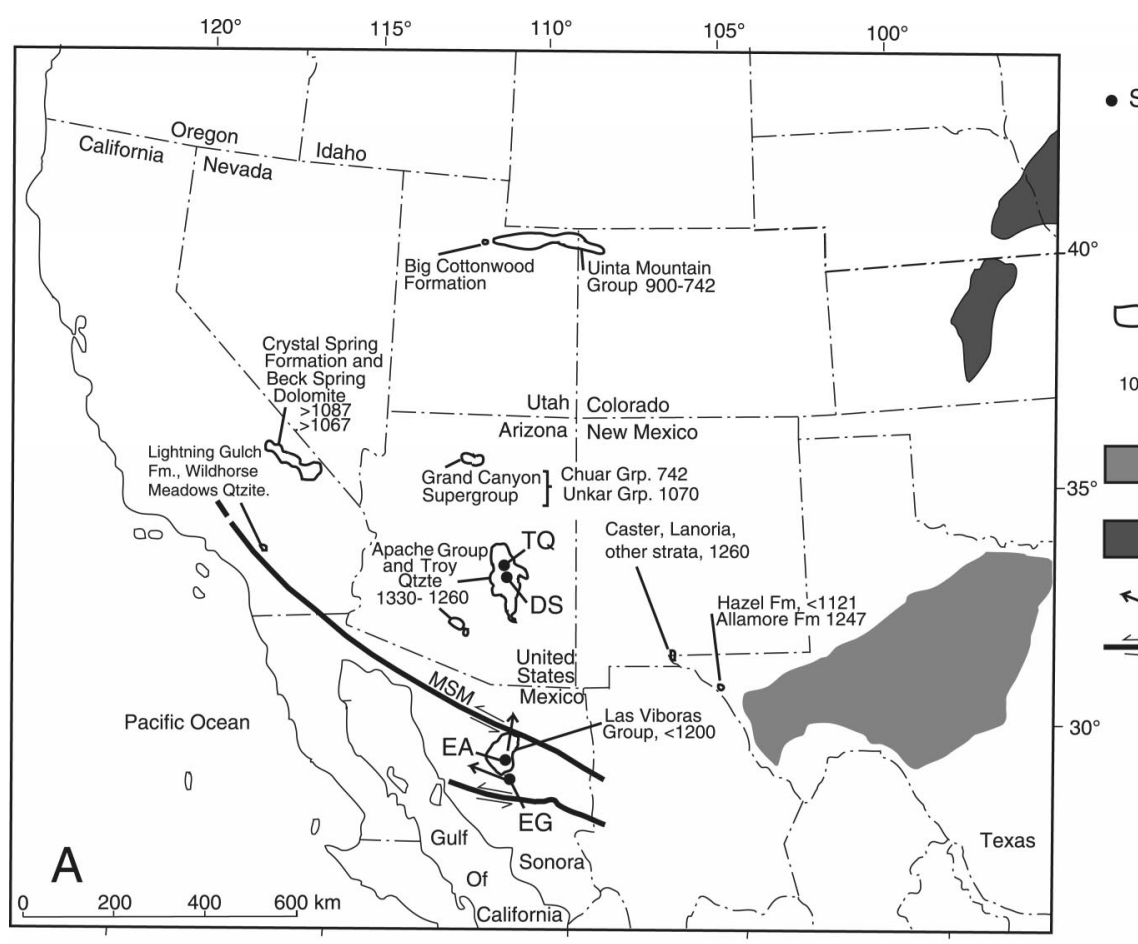

- Sample locality

TQ, Troy Quartzite

DS, Dripping Spring

Quartzite

EA, El Alamo Formation

$E G$, El Aguila unit

Generalized outcrop of

Mesoproterozoic and/or

Neoproterozoic rocks.

1070 Age (Ma) of unit indicated.

Grenville province

(Llano terrane, 1326-1070 Ma)

Midcontinent Rift System 1109-1087 Ma

$\checkmark$ Generalized paleocurrent direction

$\leftrightharpoons$ Hypothetical left-lateral Permian or Mesozoic fault. MSM, MojaveSonora megashear

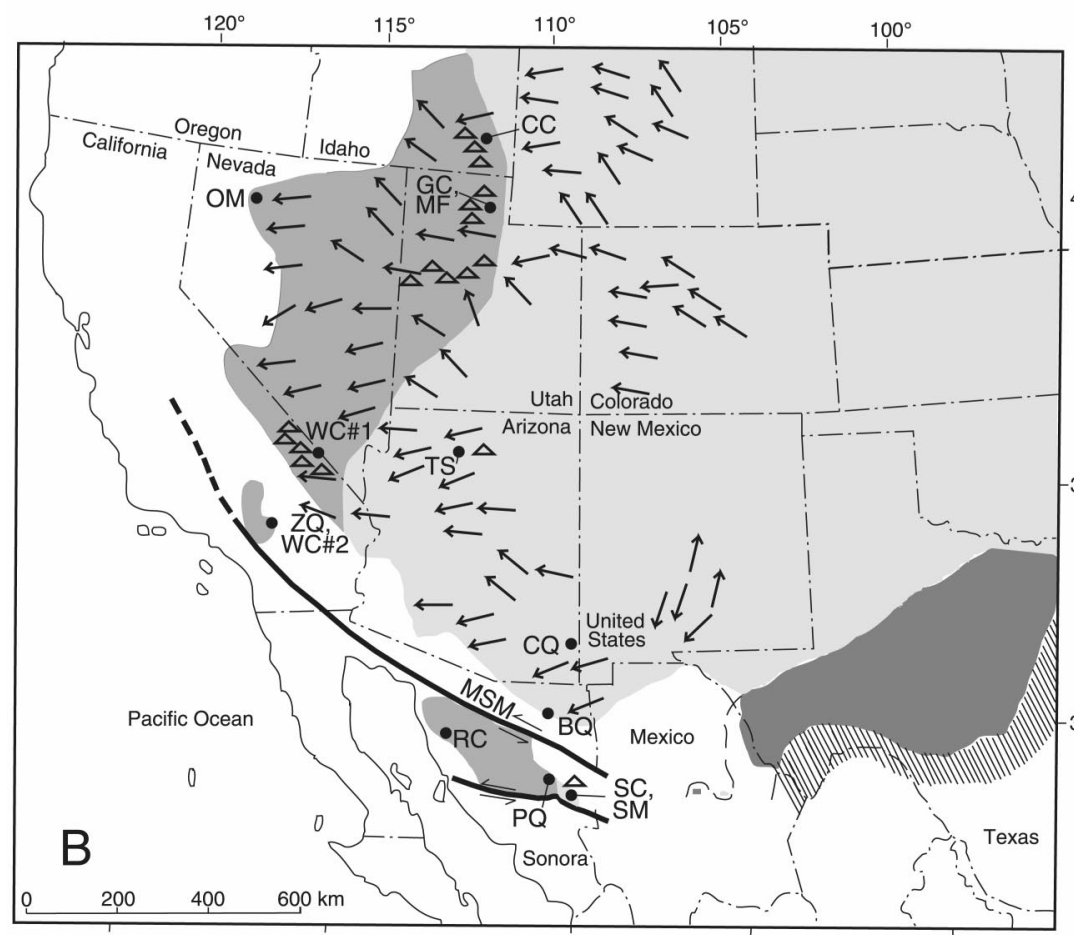
- Sample locality
CC, Caddy Canyon
GC, Gertsen Canyon
MF, Mutual Formation
OM, Osgood Moutain Quartzite
WC\#1, Wood Canyon Formation \#1
TS, Tapeat Sandstone
ZQ, Zabriskie Quartzite
WC\#2, Wood Canyon Formation \#2
$\mathrm{CQ}$, Coronado Quartzite
$\mathrm{BQ}$, Bolsa Quartzite
$\mathrm{PQ}$, Proveedora Quartzite
RC, Rancho Curiel
SC, Sierra Chiltepin Formation
SM, Sahuaripa Member
$35^{\circ} \quad$ Cratonal cover strata. Include
areas where Cambrian rocks were not deposited and/or were eroded during Paleozoic time
Cordilleran miogeoclinal shelf
Grenville province
(Llano terrane)
$30^{\circ} \mathrm{Mm}$ Ouachita orogenic belt
$\Delta$ Generalized distribution of diamictite(tillite) and associated strata
$\sqrt{ }$ Generalized paleocurrent directions. Mostly from Seeland (1968, fig. 30).
$\leftrightharpoons$ Hypothetical left-lateral Permian or Mesozoic fault. MSM, Mojave- Sonora megashear

Figure 1. Stratigraphic and tectonic setting of samples. (A) Mesoproterozoic and/or Neoproterozoic pre-Rodinian and Rodinian strata. (B) Uppermost Neoproterozoic and Cambrian strata. Localities SC and SM are Cordilleran inland strata. Based on many sources including Stewart (1991), Heaman and Grotzinger (1992), Link and et al. (1993), Mosher (1998), and Karlstrom et al. (2000). 
TABLE 1. STRATIGRAPHIC UNIT, AGE OF UNIT, AND LOCATION OF SAMPLE

\begin{tabular}{|c|c|c|c|c|}
\hline \multirow[t]{2}{*}{ Stratigraphic unit } & \multirow[t]{2}{*}{ Age } & \multicolumn{3}{|c|}{ Location } \\
\hline & & Place name & $\begin{array}{l}\text { Latitude } \\
\left({ }^{\circ} \mathrm{N}\right)\end{array}$ & $\begin{array}{l}\text { Longitude } \\
\left({ }^{\circ} \mathrm{W}\right)\end{array}$ \\
\hline \multicolumn{5}{|l|}{ Cratonal cover } \\
\hline $\begin{array}{l}\text { Coronado Sandstone } \\
\text { Bolsa Quartzite } \\
\text { Tapeats Sandstone } \\
\text { Cordilleran miogeocline } \\
\end{array}$ & $\begin{array}{l}\text { Late Cambrian } \\
\text { Middle and Early? Cambrian } \\
\text { Middle and Early? Cambrian }\end{array}$ & $\begin{array}{l}\text { Cochise County, Arizona } \\
\text { Bacoachi, Sonora, Mexico } \\
\text { Grand Canyon, Arizona }\end{array}$ & $\begin{array}{l}32^{\circ} 9.84^{\prime} \\
30^{\circ} 36.8^{\prime} \\
36^{\circ} 05.4^{\prime}\end{array}$ & $\begin{array}{l}109^{\circ} 26.73^{\prime} \\
109^{\circ} 56.9^{\prime} \\
112^{\circ} 07.47^{\prime}\end{array}$ \\
\hline $\begin{array}{l}\text { Proveedora Quartzite } \\
\text { Zabriskie Quartzite } \\
\text { Wood Canyon Formation \#2 } \\
\text { Wood Canyon Formation \#1 } \\
\text { Osgood Mountain Quartzite } \\
\text { Geersten Canyon Quartzite } \\
\text { Mutual Formation } \\
\text { Caddy Canyon Quartzite } \\
\text { Rancho Curiel unit } \\
\text { Cordilleran Inland }\end{array}$ & $\begin{array}{l}\text { Early Cambrian } \\
\text { Early Cambrian } \\
\text { Neoproterozoic and Early Cambrian } \\
\text { Neoproterozoic and Early Cambrian } \\
\text { Early Cambrian } \\
\text { Neoproterozoic and/or Earily Cambrian } \\
\text { Neoproterozoic } \\
\text { Neoproterozoic } \\
\text { Neoproterozoic }\end{array}$ & $\begin{array}{l}\text { Sierra Agua Verde, Sonora, Mexico } \\
\text { San Bernardino Mountains, California } \\
\text { San Bernardino Mountains, California } \\
\text { Pahrump Valley, California } \\
\text { Osgood Mountains, Nevada } \\
\text { Huntsville area, Utah } \\
\text { Huntsville area, Utah } \\
\text { Portneuf Range, Idaho } \\
\text { Félix Gómez region, Sonora, Mexico }\end{array}$ & $\begin{array}{l}29^{\circ} 12.0^{\prime} \\
34^{\circ} 18.6^{\prime} \\
34^{\circ} 18.6^{\prime} \\
35^{\circ} 46.5^{\prime} \\
41^{\circ} 58.4^{\prime} \\
41^{\circ} 15.9^{\prime} \\
41^{\circ} 15.95^{\prime} \\
42^{\circ} 50.617^{\prime} \\
29^{\circ} 54.1^{\prime}\end{array}$ & $\begin{array}{l}109^{\circ} 54.8^{\prime} \\
116^{\circ} 50.5^{\prime} \\
116^{\circ} 50.2^{\prime} \\
115^{\circ} 43.7^{\prime} \\
117^{\circ} 26.1^{\prime} \\
111^{\circ} 40.7^{\prime} \\
111^{\circ} 40.9^{\prime} \\
112^{\circ} 10.707^{\prime} \\
111^{\circ} 37.7^{\prime}\end{array}$ \\
\hline $\begin{array}{l}\text { Sierra Chiltepin Member } \\
\text { Sahuaripa Member } \\
\text { Rodinian epicontinental }\end{array}$ & $\begin{array}{l}\text { Neoproterozoic } \\
\text { Neoproterozoic }\end{array}$ & $\begin{array}{l}\text { Sahuaripa area, Sonora, Mexico } \\
\text { Sahuaripa area, Sonora, Mexico }\end{array}$ & $\begin{array}{l}29^{\circ} 00.5^{\prime} \\
29^{\circ} 00.9^{\prime}\end{array}$ & $\begin{array}{l}109^{\circ} 17.6^{\prime} \\
109^{\circ} 17.3^{\prime}\end{array}$ \\
\hline $\begin{array}{l}\text { El Aguila unit } \\
\text { El Alamo Formation } \\
\text { PreRodinian epicontinental } \\
\end{array}$ & $\begin{array}{l}\text { Mesoproterozoic and/or Neoproterozoic } \\
\text { Mesoproterozoic and/or Neoproterozoic }\end{array}$ & $\begin{array}{l}\text { Sierra El Sotol area, Sonora, Mexico } \\
\text { Cerro de Oro area, Sonora, Mexico }\end{array}$ & $\begin{array}{l}29^{\circ} 26.0^{\prime} \\
29^{\circ} 35.5^{\prime}\end{array}$ & $\begin{array}{l}110^{\circ} 32.6^{\prime} \\
110^{\circ} 35.6^{\prime}\end{array}$ \\
\hline $\begin{array}{l}\text { Troy Quartzite } \\
\text { Dripping Spring Quartzite of Apache Group } \\
\text { Pioneer Shale of Apache Group }\end{array}$ & $\begin{array}{l}\text { Mesoproterozoic } \\
\text { Mesoproterozoic } \\
\text { Mesoproterozoic }\end{array}$ & $\begin{array}{l}\text { Sierra Ancha, Arizona } \\
\text { Sierra Ancha, Arizona } \\
\text { Near Globe, Arizona }\end{array}$ & $\begin{array}{l}33^{\circ} 51.8^{\prime} \\
33^{\circ} 43.7^{\prime} \\
33^{\circ} 31.05^{\prime}\end{array}$ & $\begin{array}{l}110^{\circ} 54.8^{\prime} \\
110^{\circ} 54.8^{\prime} \\
110^{\circ} 53.23^{\prime}\end{array}$ \\
\hline
\end{tabular}

are available ${ }^{1}$ ). Previous studies, in addition to those listed above, in Proterozoic and Cambrian arenites in the western United States and northern Mexico include Ross et al. (1992); Gehrels et al. (1995), Farmer and Ball (1997); and Grasse et al. (2001).

\section{SEDIMENTARY AND TECTONIC SETTING OF ARENITES}

Our samples are from five sedimentary and tectonic settings: (1) Mesoproterozoic pre-Rodinian epicontinental basins, (2) Neoproterozoic Rodinian epicontinental basins, (3) Neoproterozoic Cordilleran inland basins, (4) Cambrian and Neoproterozoic Cordilleran miogeocline, and (5) Cambrian Laurentian cratonal cover (Fig. 1).

1. Mesoproterozoic pre-Rodinian epicontinental basins formed prior to the $1.1 \mathrm{Ga}$ assembly of the hypothetical supercontinent of Rodinia (Hoffman, 1991; Dalziel, 1991, 1992; Li et al., 1995): Samples of these strata consist of one from the Dripping Spring Quartzite of the Apache Group and one from the overlying Troy Quartzite in Arizona (Table 1, Fig. 1). These strata are younger than the $1.33 \mathrm{Ga}$ age reported here for tuff in the Pioneer Shale in the lower part of the Apache Group and older than $\mathrm{U}-\mathrm{Pb}$ dates on zircons associated with $1.12-1.11 \mathrm{Ga} \mathrm{U}-\mathrm{Pb}$ dates on granophyre as-

${ }^{1}$ GSA Data Repository item 2001110, geochronologic data, is available on the Web at http:// www.geosociety.org/pubs/ft2001.htm. Requests may also be sent to editing@geosociety.org. sociated with diabase (Wrucke, 1989) that intrudes the Apache Group and Troy Quartzite. The Apache Group ranges in thickness from 335 to $490 \mathrm{~m}$ (Wrucke, 1989); it is divided, in ascending order, into the Pioneer Shale, Dripping Spring Quartzite, Mescal Limestone, and basalt. These units consist of conglomerate, sandstone, siltstone, and limestone, commonly with stromatolites, microbial laminites, and casts of evaporite minerals. Shallow-marine, tidal, and supratidal environments, including a sabkha environment, are indicated. The Troy Quartzite is as thick as $365 \mathrm{~m}$ and includes fluvial and eolian deposits. Our sample from the Troy Quartzite is from a largescale cross-stratified eolian dune deposit.

2. Neoproterozoic Rodinian epicontinental basins formed after the assembly of Rodinia at about $1.1 \mathrm{Ga}$. We studied detrital zircons from two units considered to be of this age, the El Alamo Formation of the Las Viboras Group and a quartzite in the El Aguila unit in Sonora, Mexico (Stewart and Amaya-Martinez, 1999; Table 1). Work is underway (Stewart) to describe these units in detail. Neither unit has been firmly dated. Both are younger than the $\sim 1.1$ b.y. detrital zircon they contain (Gross et al., 2000), and thus both are younger than the Apache Group and Troy Quartzite of Arizona. They are not similar in stratigraphy to the Cordilleran miogeoclinal strata at $\mathrm{Ca}$ borca and are considered older than the $\mathrm{Ca}$ borca strata. At one locality, they contain halite casts and at another, eolian deposits. Conceivably, these strata are equivalent in age to widespread Neoproterozoic strata in Australia (Warrina Supergroup) that contain casts of evaporite minerals (Preiss, 1993). These evaporite-bearing units in Australia lie stratigraphically below Sturtian glacial deposits, which are also present in Sonora (Corsetti et al., 2001).

The Las Viboras Group is about $2400 \mathrm{~m}$ thick and consists of the El Tápiro, El Alamo, and Año Nuevo Formations, composed of fluvial, tidal, and minor eolian sandstone. The El Aguila Group is poorly exposed and little studied. It appears to be at least $1000 \mathrm{~m}$ thick and composed of fluvial, tidal, and shallowmarine siltstone, sandstone, and dolomite. Paleocurrent directions are toward the north (Fig. 1) in the Las Viboras Group and to the northnorthwest at one locality in the El Aguila Group.

3. Neoproterozoic Cordilleran inland basins consist of strata near Sahuaripa, east-central Sonora. These strata include a thin diamictite and a cap carbonate assigned to the Sturtian glaciation (Corsetti et al., 2001). The entire Neoproterozoic section near Sahuaripa is 2600 m thick (Stewart and Amaya-Martinez, 1999), of which the diamictite and cap carbonate form the basal $\sim 200 \mathrm{~m}$. Paleogeographic assignment of these strata is debatable. Sturtian strata elsewhere in western North America are closely associated with the Cordilleran miogeocline. However, we here consider that these Sonora Sturtian strata lie inland of the Cordilleran miogeocline. Associated Cambrian strata are not like those in the Cordilleran 
miogeocline and are similar to Cambrian cratonal cover rocks inland of the Cordilleran miogeocline. The setting of the Sahuaripa strata may be similar to that in Australia (Powell et al., 1994), where inland Sturtian glacial deposits formed at the same time as rifting that formed the continental margin, a type of rifting that in western North America led to formation of the Cordilleran miogeocline.

The Sahuaripa strata are divided into four formations, the Mina el Mezquite, Monteso, Sierra Chiltepin, and Macho. We collected samples from a conspicuous quartzite (Sahuaripa Member) of the Monteso Formation and from coarse-grained quartzite in the lowermost part of the Sierra Chiltepin Formation. The strata of the Sahuaripa section consist of shallow-water marine carbonates, fine-grained marine siltstone, sandy dolomites and interstratified tidal or shallow-marine quartzite, and minor pebble to cobble conglomerate.

4. We studied detrital zircon from nine arenite units of the Cordilleran miogeocline (Fig. 1). These miogeoclinal strata (Stewart, 1991; Christie-Blick and Levy, 1989; Link et al., 1993) were deposited on the margin of Laurentia (ancestral North America) after the rifting and fragmentation of Rodinia at $0.7 \mathrm{Ga}$, or later. The Neoproterozoic and Cambrian miogeocline is a broad wedge-shaped continental shelf deposit that thins from $>3000 \mathrm{~m}$ in the western areas of its exposure to only a few hundred meters in eastern areas. It extends along the western border of Laurentia from Alaska to as far south as Sonora, Mexico. The miogeocline consists of fluvial to subtidal, and at one locality eolian, compositionally mature quartz arenite, feldspathic arenite, arkose, siltstone, and interstratified limestone and dolomite. The older part of the section contains glaciogenic deposits of the Sturtian and Varangian (Marinoan) glaciations, and widespread unconformities in the section are attributed to exposure of the continental shelf as a result of drawdown of the oceans during times of continental glaciation. Paleocurrent directions in the miogeocline are toward the west (Fig. 1).

The units sampled in the Cordilleran miogeocline include one from Idaho, two from Utah, one from Nevada, three from California, and two from Sonora, Mexico (Fig. 1).

5. The Cambrian cratonal cover strata in interior parts of Laurentia are a few hundred meters thick and consist of Lower?, Middle, and Upper Cambrian fluvial to subtidal conglomerate, quartzite, and sandstone units overlain by marine carbonate and siltstone (Middleton, 1989). The basal conglomerate, quartzite, and sandstone are diachronous, ranging in age from Early? Cambrian in western areas to as young as Late Cambrian in eastern areas. The cratonal cover strata lie unconformably on Proterozoic crystalline basement rocks. Paleocurrent directions in the basal conglomerate, quartzite, and sandstone are westward (Fig. 1). We sampled the basal conglomerate, quartzite, and sandstone unit in these continental cover strata at two localities in Arizona and one in northern Sonora, Mexico (Fig. 1).

\section{ANALYTICAL TECHNIQUES}

Zircons were extracted from our samples by means of standard mineral separation techniques, as described by Gehrels and Stewart (1998). Most samples yielded a typical spectrum of zircon grains that average $\sim 80 \mu \mathrm{m}$ in sieve size. Above $\sim 150 \mu \mathrm{m}$, the number of zircon grains decreases dramatically. For these samples, the $>100 \mu \mathrm{m}$ grains were grouped into populations according to color, morphology, and rounding or sphericity. Representatives of each population were selected for analysis, generally in proportion to the population abundance within the sample. Care was taken, however, to analyze at least two grains from each population in an effort to ensure that every population would be adequately represented in the final analysis. This strategy, which effectively overrepresents the minor populations and underrepresents the dominant populations, was adopted in an effort to maximize the number of different age groups recognized in each sample.

Two of our samples (Troy Quartzite and Pioneer Shale) yielded only a homogeneous population of colorless to light pink grains that are all $<100 \mu \mathrm{m}$ in sieve size. For these samples, the largest grains available $(\sim 80$ $\mu \mathrm{m})$ were analyzed.

Grains from each sample were then abraded to $\sim 70 \%$ of their original size and analyzed as individual grains by means of conventional isotope dilution-thermal ionization mass spectrometry. Total procedural blanks were $\sim 5 \mathrm{pg}$ for $\mathrm{Pb}$ and $\sim 0.5 \mathrm{pg}$ for $\mathrm{U}$. These analytical procedures yielded average uncertainties (at the $95 \%$ confidence level) of $0.83 \%$ for ${ }^{206} \mathrm{~Pb} * /$ ${ }^{238} \mathrm{U}\left(\mathrm{Pb}^{*}\right.$, radiogenic component of $\mathrm{Pb}$ in a sample) ages and $0.84 \%$ for ${ }^{207} \mathrm{~Pb} * / 206 \mathrm{~Pb}^{*}$ ages. (For isotopic data, see footnote 1).

Of the 260 grains reported in this study and the 138 additional grains used from previous studies by Gehrels and Dickinson (1995), Gehrels and Stewart (1998), and Gross et al. (2000), 176 grains (46\%) yield concordant ages, where concordance is defined by overlap of an error ellipse (at 95\% confidence level) with concordia. For these grains, crystallization ages are interpreted from the ${ }^{207} \mathrm{~Pb} * /$ ${ }^{206} \mathrm{~Pb}^{*}$ ages. For discordant grains, ${ }^{207} \mathrm{~Pb} * /$ ${ }^{206} \mathrm{~Pb}^{*}$ ages are an underestimate of crystallization age because there is no evidence for recent metamorphism or isotopic disturbance in any of the areas from which samples were collected. In most areas, the youngest widespread event of plutonism and hydrothermal activity was in Cretaceous-early Tertiary time. Data listed in GSA Data Repository accordingly includes the age of each grain assuming that discordance results from $\mathrm{Pb}$ loss at $80 \mathrm{Ma}$; an uncertainty of \pm 80 m.y. is assigned to this lower intercept to reflect the uncertainty in this age of $\mathrm{Pb}$ loss. This produces projected ages that are generally older than the ${ }^{207} \mathrm{~Pb} * / 206 \mathrm{~Pb}^{*}$ ages; the age difference increases with the degree of discordance. The age difference averages 5.7 m.y. for our entire data set; the minimum is 0.5 m.y. for the sample with the least discordance, and the maximum is $29.3 \mathrm{~m} . \mathrm{y}$. for the sample with the greatest discordance. The $\pm 80 \mathrm{~m}$.y. error assigned to this disturbance age incorporates the uncertainty in the age of $\mathrm{Pb}$ loss and produces an error in the projected ages that increases with the degree of discordance. The minimum error assigned to a projected age is $\pm 10 \mathrm{~m}$.y.

As an example of the difference between ${ }^{207} \mathrm{~Pb} * / 206 \mathrm{~Pb} *$ age and projected age, a grain that is concordant with a ${ }^{207} \mathrm{~Pb}^{*} / 206 \mathrm{~Pb}^{*}$ age of $1384 \pm 10$ Ma yields a projected age of 1384 $\pm 10 \mathrm{Ma}$. In contrast, a grain that is $40 \%$ discordant with a ${ }^{207} \mathrm{~Pb}^{*} / 206 \mathrm{~Pb}^{*}$ age of $1384 \pm 10$ Ma yields a projected age of $1433 \pm 30 \mathrm{Ma}$. We suggest that the projected ages and their uncertainties are a better estimate of crystallization age than the ${ }^{207} \mathrm{~Pb} * / 206 \mathrm{~Pb}^{*}$ ages. In discussing possible sources of our detrital zircons, we accordingly rely on the projected ages for the discordant analyses. Possible differences in interpretation based on using projected ages, versus ${ }^{207} \mathrm{~Pb} * / 206 \mathrm{~Pb} *$ ages, can be assessed using information in the GSA Data Repository (see footnote 1). In evaluating possible errors in age, it is important to note, however, that our method of analysis does not include possible complications resulting from multiple phases of $\mathrm{Pb}$ loss (and/or younger grain growth), or the possibility that discordance results from inheritance rather than (or in addition to) $\mathrm{Pb}$ loss.

Several additional uncertainties and potential biases arise from our analytical methods. One potential bias derives from the fact that we generally analyze only the coarser grains in a sample. This serves to emphasize the significance of sources that are nearby, coarser grained, and perhaps also younger (given the 


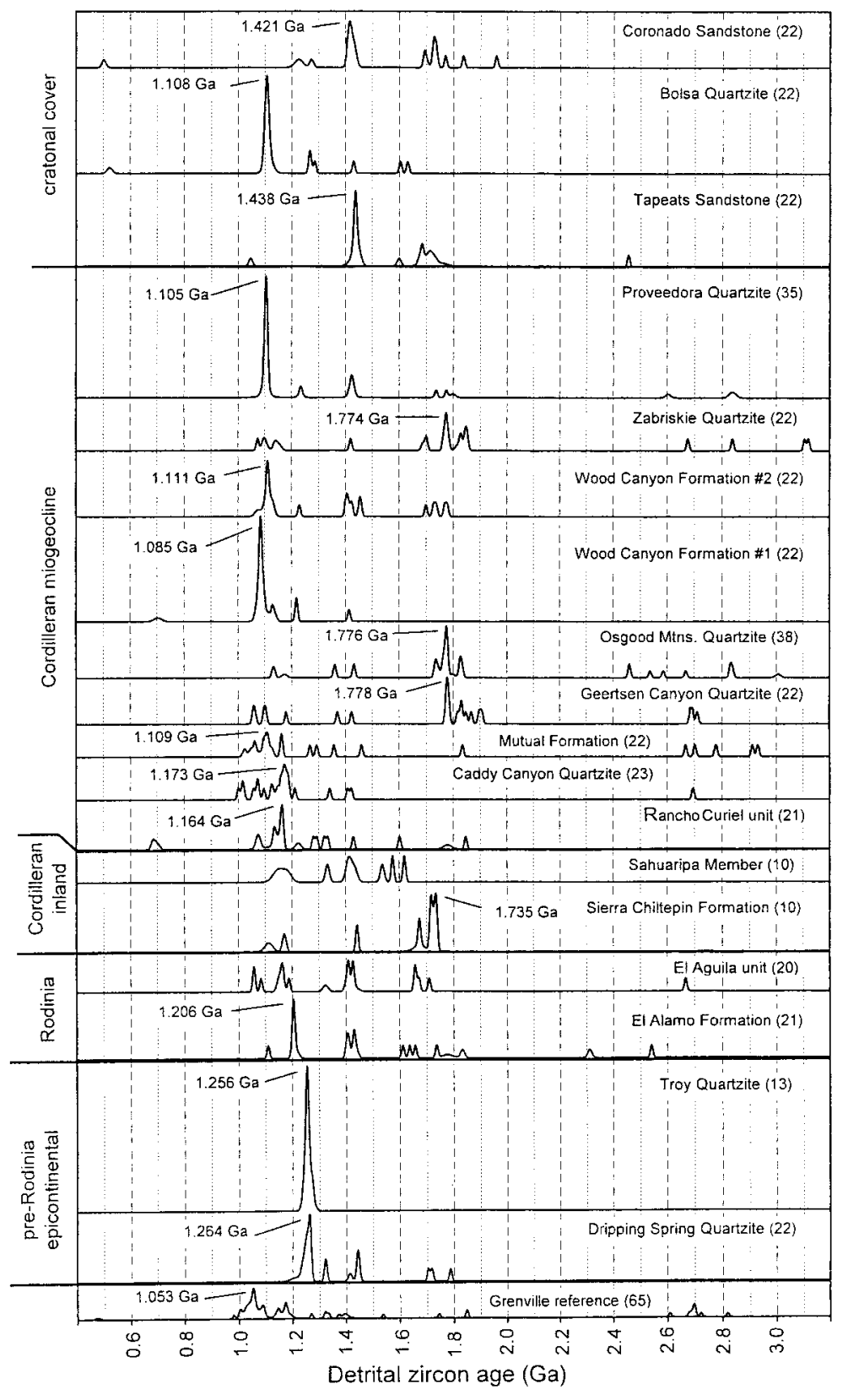

Figure 2. Relative age-probability curves, or age spectra, for all samples. Sample name and number of grains contained in each curve are shown on the right. As shown in Figure 3 , each curve incorporates the age and uncertainty (plotted as a normal probability distribution) of every grain analyzed in a sample. Each curve is normalized according to the number of constituent grains, such that each curve contains the same area. The Grenville reference represents analyses of detrital zircons in Paleozoic sandstones of the Ouachita Mountains, which consist of detritus derived from the Grenville orogen (from Gleason et al., 2001; 2001, written commun.).

fact that resistance to erosion decreases as decay-induced lattice damage accumulates). This should have little effect on the results of our study, however, because the same potential bias would exist in all of our samples. We also introduce a potential bias by selecting grains from color and morphology groups rather than by selecting grains at random. This strategy serves to maximize the number of age groups recognized within a sample, which helps in identifying a specific provenance area for a sample. However, because the proportions of age groups are affected by our grain selection procedure, comparisons with potential source

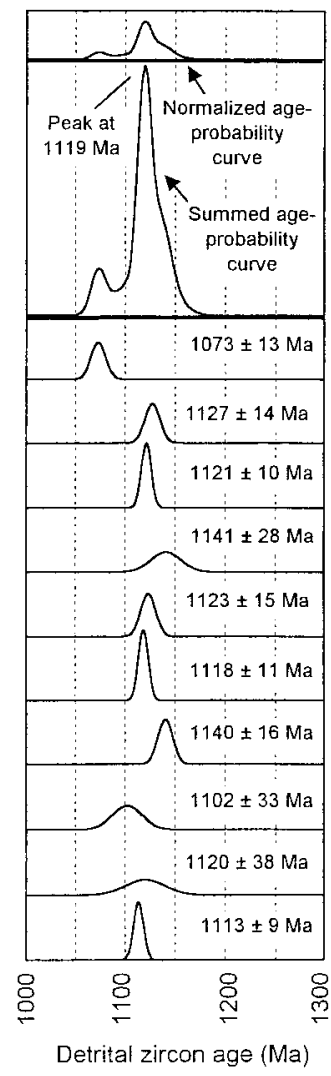

Figure 3. Example of how an age-probability curve is constructed. For each of the ten grains in this example, the age and uncertainty (stated at $95 \%$ confidence level) are plotted as a normal (or Gaussian) probability distribution. These ten probability distributions are summed, producing an age-probability curve for all of the grains. For comparison with other samples, a relative (or normalized) age-probability curve (top row) is produced by dividing the summed curve by the number of grains.

regions can be made only on the basis of whether grains of specific ages are present or absent, rather than on the relative proportions of grains of particular ages. We must also point out that we are able to resolve only the main age groups in a sample, because of the relatively small number of grains analyzed. According to the formula of Dodson et al. (1988), an age group must make up at least $15 \%$ of the grains in a sample to be recognized if 22 grains (our typical number) are analyzed.

A histogram-type plot that incorporates both the age and the associated uncertainty of each analysis (Figs. 2 and 3) is constructed as shown in Figure 3. For a sample of 10 grains, for example, each analysis is plotted as a normal (Gaussian) distribution according to its 
STEWART et al.

age and uncertainty. The area under each curve is the same, such that a well-determined age yields a tall but narrow curve, and an analysis with large uncertainty yields a low but broad curve. All of the age-probability distributions are then summed into a single curve. For comparison with other samples, the summed curve is divided by the number of constituent grains to yield a normalized ageprobability curve. This curve is referred to as a relative age-probability curve or an age spectrum for a sample.

The major peaks in age probability are labeled in Figure 2, and all of the peaks defined by at least two grains or by at least one concordant grain are listed in Table 2. This table also includes information on the reliability of the age spectra, including the number of concordant analyses, the average degree of discordance of the analyses, and the peaks that would result from plotting ${ }^{207} \mathrm{~Pb}^{*} / 206 \mathrm{~Pb}^{*}$ ages rather than projected ages. Age-probability peaks defined by two or more grains are considered to be reliable because of the low probability that two grains affected by multiple discordance mechanisms would yield the same projected age. In contrast, ages defined by only a single discordant grain are not considered further because of the possibility that discordance in the grain results from multiple discordance mechanisms.

\section{AGES OF DETRITAL ZIRCONS}

The ages of grains in our 15 new samples, and also in five samples reported by Gehrels and Dickinson (1995), Gehrels and Stewart (1998), and Gross et al. (2000) that are essential to our interpretations, are reported in the GSA Data Repository material (see footnote 1). In the following discussion, and also in Figure 2, these samples are discussed in order of depositional age, from oldest to youngest.

\section{Pre-Rodinia Epicontinental Samples}

\section{Pioneer Shale}

We analyzed seven zircon grains from a sample of tuff or reworked tuff in the Pioneer Shale in the lower part of the Apache Group. All of the grains in the sample are $<100 \mu \mathrm{m}$, colorless to very light pink, and euhedral. Six of the seven grains analyzed are concordant to moderately discordant, with an upper-intercept age of $1328 \pm 5 \mathrm{Ma}$ and a lower intercept of $49 \pm 98 \mathrm{Ma}(\operatorname{mswd}=1.1$; Fig. 4). The seventh grain yields a much older ${ }^{207} \mathrm{~Pb} * / 206 \mathrm{~Pb} *$ age, presumably due to the presence of older inherited components.

The zircons from the Pioneer Shale were
TABLE 2. PEAKS IN AGE PROBABILITY FOR EACH SAMPLE DISCUSSED

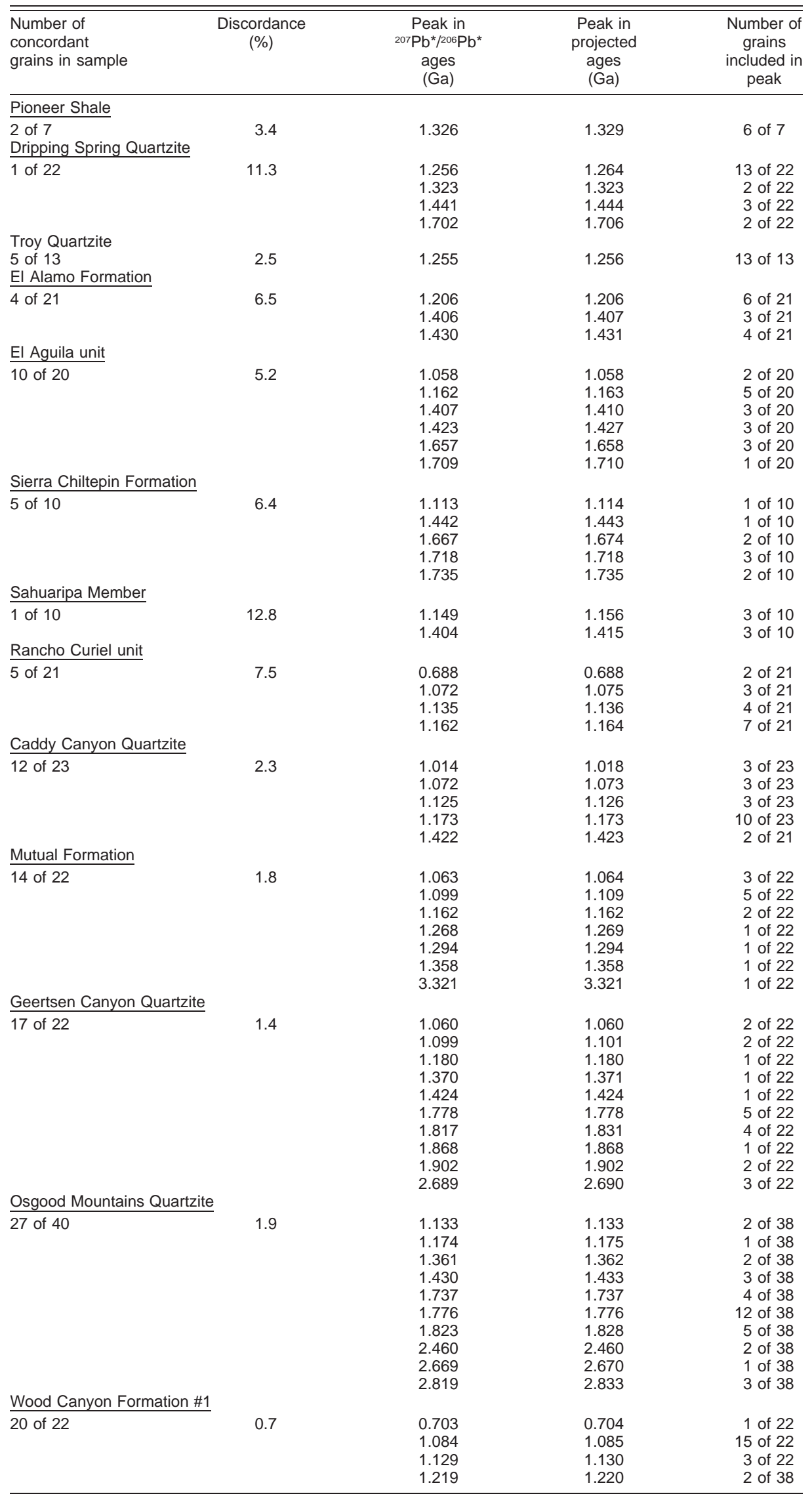


derived from a tuff, or reworked tuff, and thus the age of these zircons indicates the age of an igneous rock, or reworked igneous rock, rather than the age of detrital zircons in a sedimentary rock. Thus, we do not include the Pioneer Shale in our discussion of detrital zircons or show it in Figure 2. We do, however, indicate a few detrital zircons in other formations we studied that may have been derived from the same source as the Pioneer Shale, or a related source.

\section{Dripping Spring Quartzite}

The Dipping Spring Quartzite lies above the Pioneer Shale in the Apache Group. A sample of quartz arenite from this unit yielded predominantly light pink zircon grains that are slightly to moderately rounded. The sample contains a large number of $>100 \mu \mathrm{m}$ (sieve size) grains, and all grains analyzed were originally $125-150 \mu \mathrm{m}$ in sieve size. No euhedral grains were found. Twenty-two grains were analyzed, most of which yield slightly discordant ages (average discordance $=11.3 \%$ ). Projected ages of these grains, as shown in Figure 2, yield one main peak at $1.264 \mathrm{Ga}$ and subordinate peaks of $1.323,1.444$, and 1.706 Ga (Table 2; see also footnote 1).

\section{Troy Quartzite}

The Troy Quartzite lies unconformably above the Apache Group. Zircon grains from this quartz arenite are all colorless to very light pink, slightly rounded, and $<100 \mu \mathrm{m}$ in sieve size. The 13 grains analyzed from this sample are all concordant to slightly discordant, and all yield ages of approximately 1.256 Ga (Fig. 2).

\section{Rodinia Samples}

\section{El Alamo Formation}

As reported by Gross et al. (2000), a sample of coarse-grained arkosic sandstone from this unit yielded predominantly large, slightly to moderately rounded grains, most of which are light pinkish in color, and a subordinate population of smaller euhedral grains that are mainly colorless. Twenty-one grains were analyzed from the various size and color groups; four are concordant and the rest are slightly to moderately discordant. A dominant peak, defined by six grains, is at $1.206 \mathrm{Ga}$, and minor peaks in age probability occur at 1.407 and $1.431 \mathrm{Ga}$ (Fig. 2; see also footnote 1). There is no strong correlation between age and either color or rounding, except that all five of the $>1.7 \mathrm{Ga}$ grains were moderately rounded.

TABLE 2. (Continued.)

\begin{tabular}{|c|c|c|c|c|}
\hline $\begin{array}{l}\text { Number of } \\
\text { concordant } \\
\text { grains in sample }\end{array}$ & $\begin{array}{c}\text { Discordance } \\
(\%)\end{array}$ & $\begin{array}{c}\text { Peak in } \\
{ }^{207} \mathrm{~Pb}^{\star} / 206 \mathrm{~Pb}^{*} \\
\text { ages } \\
(\mathrm{Ga})\end{array}$ & $\begin{array}{l}\text { Peak in } \\
\text { projected } \\
\text { ages } \\
(\mathrm{Ga})\end{array}$ & $\begin{array}{l}\text { Number of } \\
\text { grains } \\
\text { included in } \\
\text { peak }\end{array}$ \\
\hline \multicolumn{5}{|c|}{ Wood Canyon Formation \#2 } \\
\hline 9 of 22 & 4.3 & $\begin{array}{l}1.110 \\
1.402 \\
1.454 \\
1.728 \\
1.779\end{array}$ & $\begin{array}{l}1.111 \\
1.407 \\
1.456 \\
1.728 \\
1.779\end{array}$ & $\begin{array}{l}10 \text { of } 22 \\
4 \text { of } 22 \\
2 \text { of } 22 \\
1 \text { of } 22 \\
1 \text { of } 22\end{array}$ \\
\hline \multicolumn{5}{|l|}{ Zabriskie Quartzite } \\
\hline 12 of 22 & 2.5 & $\begin{array}{l}1.074 \\
1.098 \\
1.139 \\
1.421 \\
1.695 \\
1.774 \\
1.829 \\
1.846 \\
2.677 \\
3.106\end{array}$ & $\begin{array}{l}1.074 \\
1.098 \\
1.140 \\
1.421 \\
1.701 \\
1.774 \\
1.829 \\
1.847 \\
2.677 \\
3.106\end{array}$ & $\begin{array}{l}1 \text { of } 22 \\
2 \text { of } 22 \\
2 \text { of } 22 \\
1 \text { of } 22 \\
2 \text { of } 22 \\
5 \text { of } 22 \\
2 \text { of } 22 \\
3 \text { of } 22 \\
1 \text { of } 22 \\
1 \text { of } 22\end{array}$ \\
\hline \multicolumn{5}{|c|}{ Proveedora Quartzite } \\
\hline 17 of 35 & 7.2 & $\begin{array}{l}1.104 \\
1.235 \\
1.420 \\
1.737 \\
1.775\end{array}$ & $\begin{array}{l}1.105 \\
1.235 \\
1.425 \\
1.737 \\
1.775\end{array}$ & $\begin{array}{l}22 \text { of } 35 \\
2 \text { of } 35 \\
5 \text { of } 35 \\
1 \text { of } 35 \\
1 \text { of } 35\end{array}$ \\
\hline \multicolumn{5}{|c|}{ Tapeats Sandstone } \\
\hline 1 of 22 & 29.8 & $\begin{array}{l}1.047 \\
1.433 \\
1.684 \\
1.708\end{array}$ & $\begin{array}{l}1.047 \\
1.438 \\
1.685 \\
1.714\end{array}$ & $\begin{array}{l}1 \text { of } 22 \\
11 \text { of } 22 \\
4 \text { of } 22 \\
2 \text { of } 22\end{array}$ \\
\hline \multicolumn{5}{|l|}{ Bolsa Quartzite } \\
\hline 14 of 22 & 3.2 & $\begin{array}{l}0.521 \\
1.107 \\
1.265 \\
1.430 \\
1.631\end{array}$ & $\begin{array}{l}0.525 \\
1.108 \\
1.266 \\
1.431 \\
1.632\end{array}$ & $\begin{array}{c}1 \text { of } 22 \\
14 \text { of } 22 \\
1 \text { of } 22 \\
1 \text { of } 22 \\
1 \text { of } 22\end{array}$ \\
\hline \multicolumn{5}{|c|}{ Coronado Sandstone } \\
\hline 1 of 22 & 17.4 & $\begin{array}{l}0.502 \\
1.215 \\
1.412 \\
1.682 \\
1.716\end{array}$ & $\begin{array}{l}0.503 \\
1.227 \\
1.421 \\
1.694 \\
1.729\end{array}$ & $\begin{array}{l}1 \text { of } 22 \\
2 \text { of } 22 \\
9 \text { of } 22 \\
2 \text { of } 22 \\
4 \text { of } 22\end{array}$ \\
\hline
\end{tabular}

Note: Age peaks are determined by peak values of the normalized age-probability curve (Fig. 2) for each sample.

\section{El Aguila Unit}

Gross et al. (2000) reported that a coarse arkosic sandstone from this unit yielded primarily slightly rounded grains, with a subordinate population of euhedral crystals. Colors are evenly split between colorless and light pink grains. Twenty grains were analyzed, of which ten are concordant, nine are slightly discordant, and one is highly discordant. Six age peaks are defined: 1.058, 1.163, 1.410, 1.427, 1.658, and $1.710 \mathrm{Ga}$ (Fig. 2, Table 2). There is no discernible relationship between age and morphology.

\section{Cordilleran Inland Samples}

\section{Sierra Chiltepin Formation}

A sample of coarse-grained quartz arenite from this unit yielded a large number of $>100$ $\mu \mathrm{m}$ zircons. Most are light to medium pink and slightly rounded. Of the ten $\sim 150 \mu \mathrm{m}$ grains analyzed, five are concordant and five are slightly to moderately discordant. Six of the grains yield ages that are $>1.6 \mathrm{Ga}$; age peaks are at $1.674,1.718$, and $1.735 \mathrm{Ga}$. There are also two concordant grains with ages of $\sim 1.114$ and $\sim 1.443 \mathrm{Ga}$.

\section{Sahuaripa Member}

A sample of medium-grained quartz arenite was processed for zircons, almost all of which are $<125 \mu \mathrm{m}$ in sieve size. Most of the grains are slightly rounded, and they range from colorless to medium pink. Of the ten $\sim 100 \mu \mathrm{m}$ grains analyzed, only one is concordant; the rest are moderately to highly discordant. Two age peaks are apparent, at 1.156 and $1.415 \mathrm{Ga}$.

\section{Cordilleran Miogeocline Samples}

\section{Rancho Curiel Unit}

This sample was collected from a quartz arenite. Recovered zircons are mainly pinkish 


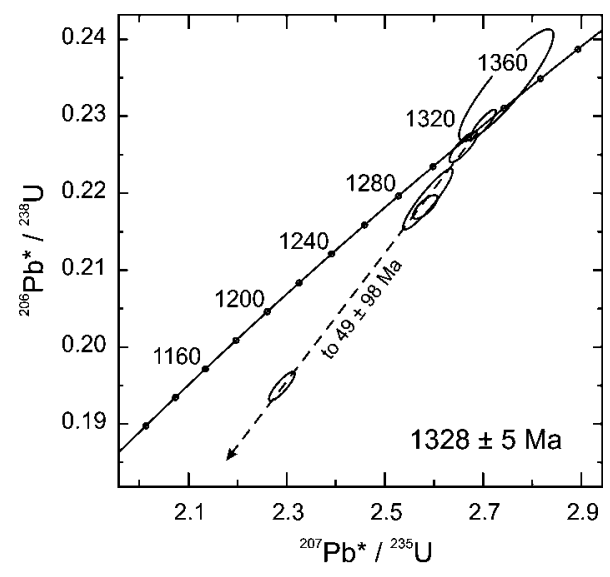

Figure 4. U-Pb concordia diagram of single detrital zircon grains from a tuff in the Pioneer Shale. Errors for each analysis are shown at the $95 \%$ confidence level. The regression line yields an upper intercept of $1328 \pm 5 \mathrm{Ma}(95 \%$ confidence level), which is interpreted as the crystallization age. The lower intercept of $49 \pm 98 \mathrm{Ma}$ is interpreted as the age of $\mathrm{Pb}$ loss.

and moderately to well rounded. There is also a subordinate $(\sim 5 \%)$ population of yellowish crystals that are slightly rounded. Three yellowish grains were analyzed; two combine to form an age-probability peak at $688 \mathrm{Ma}$. Eighteen grains from the other color groups yield mainly slightly discordant analyses, three concordant analyses, and one highly discordant analysis. Age peaks include a dominant peak at $1.164 \mathrm{Ga}$ and subordinate peaks at 1.075 and $1.136 \mathrm{Ga}$.

\section{Caddy Canyon Quartzite}

The sample collected from this unit is a feldspathic arenite. Zircons are mainly light to medium pink and moderately to highly rounded. Twelve of the 23 grains analyzed yield concordant ages, and most of the rest are only slightly discordant. There is a dominant age peak at $1.173 \mathrm{Ga}$ and subordinate peaks at $1.018,1.073,1.126$, and $1.423 \mathrm{Ga}$. There is no apparent correlation between grain type and age.

\section{Mutual Formation}

Zircons were extracted from a quartz arenite of the Mutual Formation. Abundant zircons up to $175 \mu \mathrm{m}$ were recovered from this unit. Most grains are well rounded and pink. Twenty-two grains averaging $\sim 150 \mu \mathrm{m}$ in sieve size were analyzed. Of these, 14 grains are concordant; 13 of these are younger than 1.4 $\mathrm{Ga}$, and most of the grains older than $1.4 \mathrm{Ga}$ are only slightly discordant. A dominant age peak is present at $1.109 \mathrm{Ga}$, subordinate peaks are present at 1.064 and $1.162 \mathrm{Ga}$, and concordant single grains are dated at about 1.269, 1.294, 1.358, and $3.321 \mathrm{Ga}$.

\section{Geertsen Canyon Quartzite}

The quartz arenite sample collected from this unit contains a large number of $>100$ $\mu \mathrm{m}$ grains, most of which are pinkish and well rounded. Twenty-two $\sim 150 \mu \mathrm{m}$ grains were analyzed; seventeen are concordant, and the rest are slightly discordant. Age peaks are present at 1.060, 1.101, 1.778, 1.831, 1.902, and $2.690 \mathrm{Ga}$, and there are concordant single grains at about 1.180, 1.371, 1.424, and $1.868 \mathrm{Ga}$.

\section{Osgood Mountains Quartzite}

As described by Gehrels and Dickinson (1995), the sample analyzed is from a metamorphosed quartz arenite. Zircons from this sample are all well rounded, and most are pinkish. Of the 40 grains analyzed, 27 are concordant, and the rest range from slightly to highly discordant. There is a single dominant age peak at $1.776 \mathrm{Ga}$, and numerous subordinate age peaks are at $1.133,1.362,1.433$, $1.737,1.828,2.460$, and $2.833 \mathrm{Ga}$; concordant single grains are at about 1.175 and $2.670 \mathrm{Ga}$.

\section{Wood Canyon Formation}

The two samples collected from this formation are both feldspathic arenites. Zircons in the two samples are generally $<150 \mu \mathrm{m}$ in sieve size; several hundred grains are between 100 and $150 \mu \mathrm{m}$ in each sample. Both samples contain predominantly light pink grains and a subordinate number of colorless grains. Most grains in sample 1 are euhedral to slightly rounded, whereas all of the grains in sample 2 are moderately rounded. There is also a minor population of yellowish, slightly rounded grains in sample 1 . Of the 22 grains analyzed from each unit, 20 are concordant in sample 1 and nine are concordant in sample 2. Most of the remaining grains in both samples are only slightly discordant. Both samples are dominated by single age peaks at $1.085 \mathrm{Ga}$ (sample 1) and $1.111 \mathrm{Ga}$ (sample 2); subordinate peaks are at 1.130 and $1.220 \mathrm{Ga}$ (sample 1) and 1.407 and $1.456 \mathrm{Ga}$ (sample 2). Concordant single grains yield ages of $\sim 704$ Ma in sample 1 , and $\sim 1.728$ and $\sim 1.779 \mathrm{Ga}$ in sample 2. There is no apparent correlation between age and color in sample 1, but in sample 2 most colorless grains are dated at $<1.2 \mathrm{Ga}$ and most pinkish grains at $>1.2 \mathrm{Ga}$.

\section{Zabriskie Quartzite}

A sample of quartz arenite was collected from this unit. Zircons from the sample are mostly $<125 \mu \mathrm{m}$ in sieve size; only $\sim 100$ grains are in the $100-125 \mu \mathrm{m}$ range. Most grains in the various size ranges are well rounded; there are both colorless and pinkish grains. Of the 22 grains analyzed, 12 are concordant, and the rest are only slightly discordant. There is a dominant age peak at 1.774 $\mathrm{Ga}$, subordinate peaks at $1.098,1.140,1.701$, 1.829 , and $1.847 \mathrm{Ga}$, and concordant single grains at about 1.074, 1.421, 2.677, and 3.106 $\mathrm{Ga}$. There is a strong correlation between color and age, only colorless grains yielding ages $<1.4 \mathrm{Ga}$ and only pinkish grains yielding $>1.4 \mathrm{Ga}$ ages.

\section{Proveedora Quartzite}

Gehrels and Stewart (1998) reported U-Pb data from this quartz arenite, which is correlative to the Zabriskie Quartzite described above. This sample yielded a large number of zircon grains up to $\sim 250 \mu \mathrm{m}$ in sieve size. Most grains are well rounded; common colors are pinkish, yellowish, and colorless. Thirtyfive $\sim 150 \mu \mathrm{m}$ grains were analyzed; 17 are concordant, and the rest are slightly to moderately discordant. There is a single dominant peak at $1.105 \mathrm{Ga}$, minor peaks at 1.235 and $1.425 \mathrm{Ga}$, and single concordant grains at about 1.737 and $1.775 \mathrm{Ga}$. The only apparent correlation between color and age is that most grains older than $1.7 \mathrm{Ga}$ are a dark pinkish color.

\section{Cratonal Cover Samples}

\section{Tapeats Sandstone}

This medium-grained quartz arenite yielded zircons that are euhedral to slightly rounded and colorless to very light pink. All grains are $<125 \mu \mathrm{m}$ in sieve size. Twenty-two $\sim 100$ $\mu \mathrm{m}$ grains were analyzed; one grain is concordant, and the rest are slightly to highly discordant. In spite of this high level of discordance, most grains are contained within one dominant peak at $1.438 \mathrm{Ga}$ and subordinate peaks at 1.685 and $1.714 \mathrm{Ga}$. The single concordant grains yields a date of about $1.047 \mathrm{Ga}$.

\section{Bolsa Quartzite}

As described by Gross et al. (2000), the sample collected from this unit is a mediumto coarse-grained quartz arenite. Most zircons extracted are slightly to moderately rounded and pink; there are subordinate colorless and euhedral populations. Of the 22 grains analyzed, 14 are concordant, and the rest are slightly to moderately discordant. There is one 
main age peak at $1.108 \mathrm{Ga}$, which contains most of the grains analyzed, and there are concordant single grains at about $525 \mathrm{Ma}$, and about $1.266,1.431$, and 1.632 Ga.

\section{Coronado Sandstone}

Zircons from the coarse-grained quartz arenite collected from this unit are as much as $250 \mu \mathrm{m}$ in sieve size. Most grains are light pink, some are colorless, and all are slightly to moderately rounded. Of the 22 grains analyzed, one is concordant, and most of the rest are moderately discordant. A dominant age peak is apparent at $1.421 \mathrm{Ga}$, subordinate peaks are at $1.227,1.694$, and $1.729 \mathrm{Ga}$, and a concordant single grain is dated at about 503 Ma.

\section{GENERAL AGE CATEGORIES OF DETRITAL ZIRCONS}

Detrital zircons as old as $3.36 \mathrm{Ga}$ and as young as $0.5 \mathrm{Ga}$ are present in the Mesoproterozoic to Upper Cambrian arenites (Fig. 2). In the range from 3.36 to $2.31 \mathrm{Ga}$, zircons are relatively sparse, and no zircons were found in the range from 2.31 to $1.96 \mathrm{Ga}$. All the remaining zircons range from about 1.91 to $1.0 \mathrm{Ga}$, except for two samples that contain zircons dated as about $0.7 \mathrm{Ga}$ (Wood Canyon Formation \#1; Rancho Curiel unit) and two samples that contains zircons dated as $0.5 \mathrm{Ga}$ (Coronado Sandstone and Bolsa Quartzite)

In the 1.91 to $1.0 \mathrm{Ga}$ range, the majority of zircons are in three groups, 1.9 to $1.6,1.45$ to 1.40 , and 1.2 to $1.0 \mathrm{Ga}$. Conspicuous spikes in the age distributions of some samples are present at about 1.77, 1.43, 1.26, 1.20, and $1.11 \mathrm{Ga}$. Conspicuous spikes at $1.26 \mathrm{Ga}$ in the Troy Quartzite and Dripping Spring Quartzite are unknown in other detrital zircon samples in our study. All 13 zircons analyzed from the Troy Quartzite are 1.26 Ga.

The zircon age spectra change somewhat with the age of the arenites. Tuff in the Pioneer Shale, which is the oldest unit studied, is dated as $1.328 \mathrm{Ga}$, and sparse detrital zircon grains of about this same age are found in the Sahuaripa Member, Rancho Curiel unit, Dripping Spring Quartzite, and El Aguila unit. The next youngest units, the Dripping Spring Quartzite and Troy Quartzite, are marked by a $1.26 \mathrm{Ga}$ spike, as indicated above. The next younger units (El Alamo Formation, the El Aguila unit, the Caddy Canyon Quartzite, $\mathrm{Mu}$ tual Formation, Geertsen Canyon Quartzite, and Osgood Mountain Quartzite) are somewhat similar to each other in that detrital zircon ranging from 1.9 to $1.0 \mathrm{Ga}$ is abundant. The El Aguila unit, Rancho Curiel unit, Caddy
Canyon Quartzite, Mutual Formation, and Geertsen Canyon Quartzite contain large proportions of 1.2 to $1.0 \mathrm{Ga}$ zircons and lesser proportions of 1.43 to $1.40 \mathrm{Ga}$ zircons; in addition, the Geertsen and Osgood Mountain quartzites contain abundant grains dating to 1.92 to $1.72 \mathrm{Ga}$. Detrital zircons in the Sierra Chiltepin Formation and Sahuaripa Member resemble the El Aguila unit, Rancho Curiel unit, Caddy Canyon Quartzite, Mutual Formation, and Geertsen Canyon Quartzite, but differ in important details. The Sierra Chiltepin contains abundant detrital zircons centered on $1.735 \mathrm{Ga}$, an age not common in other samples. The Sahuaripa member contains two grains of about $1.577 \mathrm{Ga}$, an age unknown in any other samples. The Wood Canyon Formation, Zabriskie Quartzite, and Proveedora Quartzite are similar in that the age spectra contains spikes of $1.11 \mathrm{Ga}$ zircon. In addition, the samples contain common 1.45 to $1.40 \mathrm{Ga}$ zircons. The Tapeats Sandstone, Bolsa Quartzite, and Coronado Sandstone, the youngest arenites, do not have a consistent zircon population pattern. A $1.11 \mathrm{Ga}$ spike in the age spectra is present in the sample of the Bolsa Quartzite, but this spike is absent in the samples of the Coronado Sandstone and Tapeats Sandstone. A $1.43 \mathrm{Ga}$ spike is present in the age spectra of the Tapeats Sandstone and Coronado Sandstone samples, but is represented by only a few zircons in the sample of the Bolsa Quartzite. The distribution of zircons of other ages in these three samples is variable.

\section{SOURCES OF THE DETRITAL ZIRCONS}

As described below, detrital zircons in the Mesoproterozoic to Cambrian arenites of the western United States and northern Mexico have inferred initial sources in Precambrian crystalline basement rocks and in supracrustal Mesoproterozoic to Neoproterozoic silicicvolcanic rocks. Sources in continental blocks now rifted from North America also are also proposed.

\section{Sources in Precambrian Crystalline Basement Rocks}

Most of the zircons in the arenites in the western United States and northern Mexico are considered to have been initially derived from crystalline basement rocks. The oldest detrital zircons (3.36 to $2.31 \mathrm{Ga}$ ) are apparently from inland parts of the North American continent, or perhaps also from recycled zircons in 1.7 to $1.8 \mathrm{Ga}$ metamorphosed sediments in the Mojave province (Barth et al., 2000b) In particular, the few grains older than 3.0 Ga might have had a source in the Wyoming province or its extension into Canada (Fig. 5), where rocks of such age are known (Houston et al., 1993). No detrital zircons ranging from 2.31 to $1.96 \mathrm{Ga}$ were found in our samples. This is an age of little tectonic or igneous activity in most cratonal areas of the western United States (Houston et al., 1993; Van Schmus et al., 1993), but such times of igneous activity are common in Canada (Hoffman, 1989).

Fairly abundant zircons ranging from 1.9 to 1.6 Ga are present in our samples. These ages correspond fairly closely to ages of basement rocks in the southwestern United States, mainly the Yavapai province (1.8 to $1.7 \mathrm{Ga}$ crust, deformed in about $1.7 \mathrm{Ga}$ during the Yavapai orogeny) and Mazatzal province (1.8 to 1.65 Ga crust, deformed in 1.60 Mazatzal orogeny) of Arizona, New Mexico, Utah, and Colorado (Van Schmus et al., 1993) (Fig. 5). Some zircons in the 1.96 to $1.6 \mathrm{Ga}$ range may have been derived from the Mojave province of eastern California and western Arizona that contains zircons of many ages, but commonly in the range from 2.3 to $1.6 \mathrm{Ga}$.

Zircons ranging from 1.45 to $1.40 \mathrm{Ga}$ are moderately common in the samples, forming conspicuous spikes in the age population diagrams in the Coronado Sandstone and Tapeats Sandstone samples. Granitoids (socalled anorogenic granite) of this age are fairly widespread in California, Arizona, and New Mexico, and elsewhere in adjacent parts of the United States (Anderson, 1989; Van Schmus et al., 1993) (Fig. 5).

Detrital zircons ranging from 1.2 to $1.0 \mathrm{Ga}$ are abundant in our samples, which is different from the interpretation of Patchett et al. (1999), based on $\mathrm{Nd}$ isotope studies, that Grenville-age detritus did not reach the western part of Laurentia until Middle to Late Ordovician time. Some of the 1.2 to $1.0 \mathrm{Ga}$ zircons, as described below, are interpreted to have been derived from silicic volcanic sources, but other zircons may be far traveled and perhaps derived from the Grenville province (Figs. 5 and 6). Such a source is suggested by the similarity of the population distribution of zircon samples in the western North America and the Grenville province (Fig. 2). In particular, the zircon age spectra of the Caddy Canyon Quartzite, Mutual Formation, and Geertsen Canyon Quartzite of Utah and Idaho resemble the zircon age spectra from the Grenville province (Fig. 2). The Grenville province reference spectra shown in Figure 2 is constructed from detrital zircons collected from the Middle Ordovician Blakely Sand- 


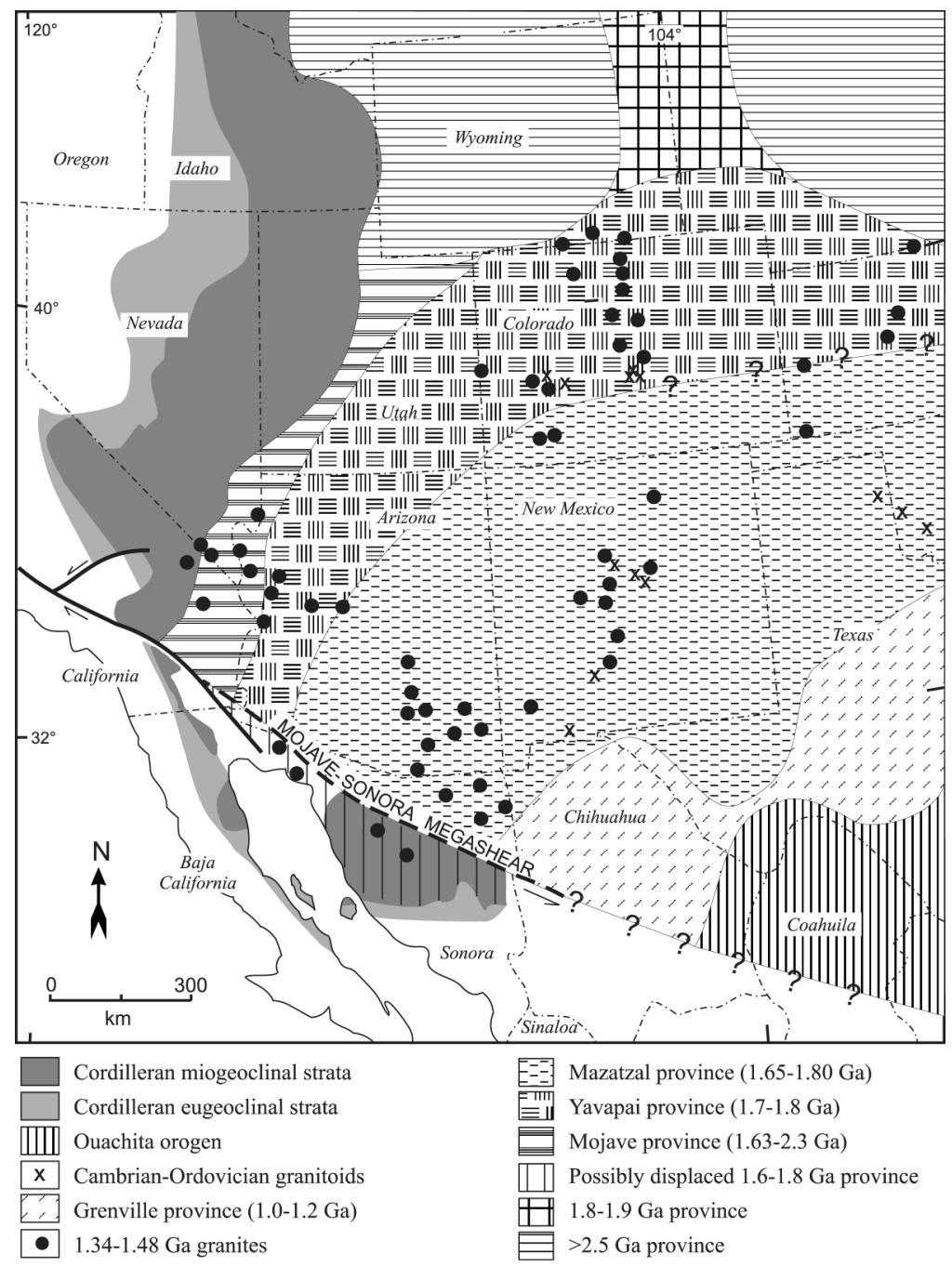

Figure 5. Ages of crystalline basement rocks in western North America (modified from Gehrels and Stewart, 1998)

stone and Upper Ordovician-Lower Silurian Blaylock Sandstone collected from Arkansas and Oklahoma, respectively. The 0.9 to $1.4 \mathrm{Ga}$ zircons are interpreted to have originated in the Grenville orogen, probably recycling through various Neoproterozoic and Ordovician units (Gleason el al, 2001; 2001, written commun.). The possibility of long-distance transport of Grenville-age detritus in Laurentia was originally proposed by Young (1979) and used by Rainbird el al (1992) to explain the presence of Grenville-age detrital zircons in northwestern Canada.

A single $0.704 \mathrm{Ga}$ zircon grain is present in the Wood Canyon Formation, and 0.685 and $0.700 \mathrm{Ga}$ zircon grains are present in the Rancho Curiel unit. Detrital zircons of this approximate time (Gehrels et al., 2000) are locally abundant in the Harmony Formation of the Roberts Mountains allochthon of Nevada.
The Harmony Formation is a poorly dated feldspathic sandstone and siltstone that has been considered to be as old as Cambrian (Stewart, 1991, and references therein) or as young as Devonian (Jones, 1997). The Harmony Formation is too young to have supplied zircon to the Neoproterozoic and Lower Cambrian units. The $0.7 \mathrm{Ga}$ date is within the 700 to $750 \mathrm{Ma}$ time interpreted to represent the time of initial rifting that led to the formation of the Cordilleran miogeocline (Stewart, 1991; Ross, 1991), and the $\sim 0.7$ Ga zircons may represent igneous activity associated with this rifting. A $0.699 \mathrm{Ga}$ date on rhyolite from interpreted rift-basin deposits in Idaho (Evans et al., 1997) is consistent with this interpretation. Campa-Uranga (1997; also cited in Burrett and Berry, 2000) reported the presence of $0.710 \mathrm{Ga}$ granites in Sonora. This information is based on an age shown in Pre- cambrian 3 map of Cook and Bally (1975), but no information concerning this age is given in references to the map. No $\sim 0.700 \mathrm{Ga}$ granites have been reported in Sonora since this 1975 report, and we do not think the age is valid.

The Bolsa Quartzite in Sonora contains one $0.525 \mathrm{Ga}$ detrital zircon, and the Coronado Sandstone in Arizona contains one $0.503 \mathrm{Ga}$ detrital zircon. This is an unusual time for igneous activity in western North America. Nevertheless, granitic rocks of this age, or of this presumed age, are present in generally small outcrop areas in Oklahoma, Texas, New Mexico, and Colorado (Loring and Armstrong, 1980; Evans and Clemens, 1988; McConnell and Gilbert, 1990; Gehrels and Dickinson, 1995), and these areas could be the source of the 0.525 to $0.503 \mathrm{Ga}$ detrital zircons in Sonora and Arizona.

\section{Sources in Supracrustal Mesoproterozoic to Neoproterozoic Silicic Volcanic Rocks}

The concept of sources in supracrustal Mesoproterozoic to Neoproterozoic volcanic rocks is based on the presence of volcanic rock or volcanic detritus in the Pioneer Shale and Dripping Spring Quartzite, both in the Apache Group, as well as in the unconformably overlying Troy Quartzite, all in Arizona. In addition, spikes in the ages of zircons in other areas suggest a local, voluminous silicic volcanic source.

The Pioneer Shale in the lower part of the Apache Group contains a tuff, or reworked tuff (Gastil, 1954), that has been dated as $1.323 \mathrm{Ga}$ (Fig. 4). Detrital zircon of approximately this age is found in the Dripping Spring Quartzite of Arizona, and in the Sahuaripa Member, Rancho Curiel unit, and Aguila unit in Sonora. These detrital zircons were derived either from the tuff in the Pioneer Shale or from igneous rocks in the unknown source area of this tuff. Alternately, other igneous sources, unknown at present, of the same age as the tuff in the Pioneer Shale, could have supplied these detrital zircons. Nevertheless, the only known unit in the western United States and northern Mexico to contain zircon of this age is tuff in the Pioneer Shale, suggesting that the tuff itself could be the source.

The Dripping Spring and Troy quartzites of Arizona are characterized by spikes of detrital zircons at $1.26 \mathrm{Ga}$, and as mentioned above, the Troy Quartzite contains zircons only of this age (Fig. 2). Such a predominance of one age of detrital zircon requires that the provenance of these units was mainly one type of 


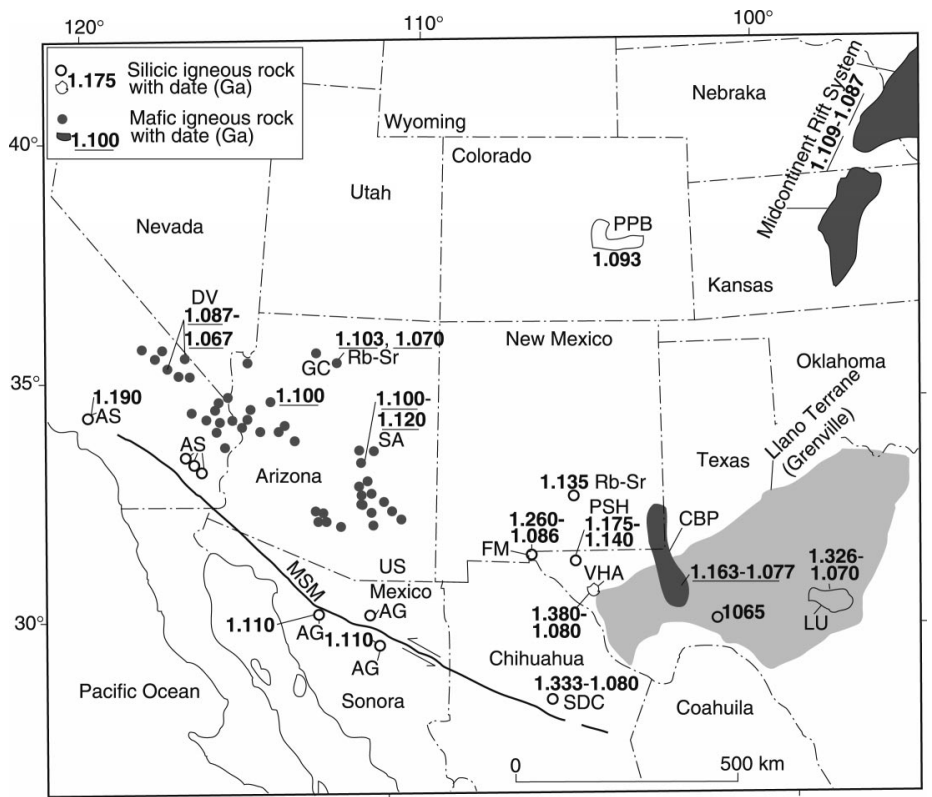

Figure 6. Distribution of 1.2 to 1.0 Ga igneous rocks in western United States and northern Mexico. All isotopic dates are by U-Pb methods except for a few that are by Rb-Sr methods (as labeled). Based on specific information, summaries, and references in the following articles: Anderson et al. (1979), Sastri et al. (1991), Howard (1991), Heaman and Grotzinger (1992), Powell (1993), Van Schmus et al. (1993), Adams and Keller (1994), Larson et al. (1994), Rodrígues-Castañeda (1994), Barth el al. (1995, 2001), Mosher (1998). AGAibo Granite; AS-Anorthosite-Syenite complex; CBP-Central Basin platform; GCGrand Canyon; DV-Death Valley; FM-Franklin Mountains; LU-Llano Uplift; MSM-Mojave-Sonora megashear; PPB_Pikes Peak batholith; PSH-Pump Stations Hills; SA-Sierra Ancha; SDC—Sierra del Cuevo; VHA-Van Horn area.

rock, and probably located near the site of deposition. Such a proximal source is likely, because a long transport distance probably would result in mixing of zircons of various ages, as is the case for most of the detrital zircons in the arenites we have studied. The most probable source that would provide abundant zircons of one age is volcanic rocks from nearby volcanic fields. Such a volcanic source is suggested by the presence of volcanic material in the Apache Group and Troy Quartzite. Possible tuff layers are present in the Dripping Spring Quartzite, and volcanic detritus is common in the Dripping Spring and Troy quartzites in southern Arizona (Nutt, 1981; J. L. Howard, 1999, written commun.). The inferred 1.26 Ga igneous event associated with the Troy Quartzite is similar in age to the 1.267 to $1.270 \mathrm{Ga}$ MacKenzie igneous events, in the northwestern Canadian shield (LeCheminant and Heaman, 1989).

Other Neoproterozoic and Cambrian arenites in the western United States and northern Mexico may have had volcanic sources. Such a possibility is revealed by distinct spikes in the age population of detrital zircons, particularly the age spike at about $1110 \mathrm{Ga}$ in the
Bolsa Quartzite, Proveedora Quartzite, and Wood Canyon Formation. In the Proveedora Quartzite, zircons of this age constitute 63\% (22 of 35 grains) of the analyzed detrital zircons. Clearly, the abundance of zircons of this age indicates a source dominated by one age of zircons. A widespread source in crystalline basement rocks, as proposed by Farmer and Ball (1997) seems unlikely because these sources generally provide zircons of a wide range of ages, not a predominance of one age. In particular, a source in the Grenville province is not considered possible because the age distribution for zircons derived from that province show a broad spectrum of ages, not a single major spike at $1.11 \mathrm{Ga}$ (see Grenville reference age spectrum, Fig. 2).

The $1.110 \mathrm{Ga}$ detrital zircon could have a source in the Pikes Peak Granite (1.093 Ga; Van Schmus et al., 1993) of Colorado or the Aibo Granite $(1.110 \mathrm{Ga}$; Anderson et al., 1979; Rodrígues-Castañeda, 1994) of Sonora (Fig. 6). The outcrop areas of these granites, however, are relatively small, and they do not seem sufficient to supply abundant $1.110 \mathrm{Ga}$ zircons to such a distant unit as the Wood Canyon Formation. A large-volume source is required because the Wood Canyon Formation and correlative rocks contain a large volume of detrital material, perhaps about 100000 $\mathrm{km}^{3}$ or approximately the size of the Sierra Nevada batholith of California and western Nevada to a depth of about $1 \mathrm{~km}$.

Perhaps other $1.1 \mathrm{Ga}$ zircon-bearing silicic sources are hidden in western North America, as proposed by Farmer and Ball (1997). Intriguingly, $1.1 \mathrm{Ga}$ diabase is moderately widespread in the western United States (Fig. 6), indicating that the ca. $1.1 \mathrm{Ga}$ igneous activity may have been regionally bimodal. A corollary of this idea is that $1.1 \mathrm{Ga}$ silicic igneous activity may have been more widespread than is currently recognized, if the volume of the diabase is any indication of the potential volume and regional extent of silicic igneous rocks.

An alternate source of the $1.1 \mathrm{Ga}$ zircons is silicic volcanic fields. This concept proposes that such rocks as the Pike Peak Granite and Aibo Granite are only the roots of major volcanic fields, and that $1.1 \mathrm{Ga}$ silicic igneous activity produced more volume than indicated by present outcrops of these granites. Other now-hidden sources for such voluminous silicic fields may exist in western North America.

In contrast to the Apache Group and Troy Quartzite that contain tuff and volcanic detritus indicative of probable volcanic source terranes, other arenites studied here contain little volcanic detritus. In Sonora, Mexico, the El Alamo Formation contains rare volcanic grains and common sericite and clay mineral grains that could be altered volcanic material. Rare grains of volcanic rock(?) were reported by Lobo and Osborne (1976) in cratonal and miogeoclinal Neoproterozoic and Cambrian arenites of southeastern California. The Wood Canyon Formation contains pebbles of volcanic rock (J.D. Cooper, 1999, written commun.), a few grains of altered shard and fibrous pumice, and as much as $25 \%$ of sand-size rounded grains and irregular masses of sericite and clay minerals (Stewart, 1970) that could be interpreted as argillite grains, weathered feldspar grains, or matrix. A small amount, or the majority, of these sericite and clay mineral grains could be of volcanic provenance. Other materials of possible volcanic origin are jasper and chalcedony clasts. Red jasper clasts have been interpreted to have been derived from Proterozoic iron-formation in Arizona (Stewart, 1970; J.L. Howard, 2000, written commun.), but a volcanic source coeval with detrital zircons is possible for some red jasper clasts. Although the amount of volcanic detritus in the Neoproterozoic and Cam- 

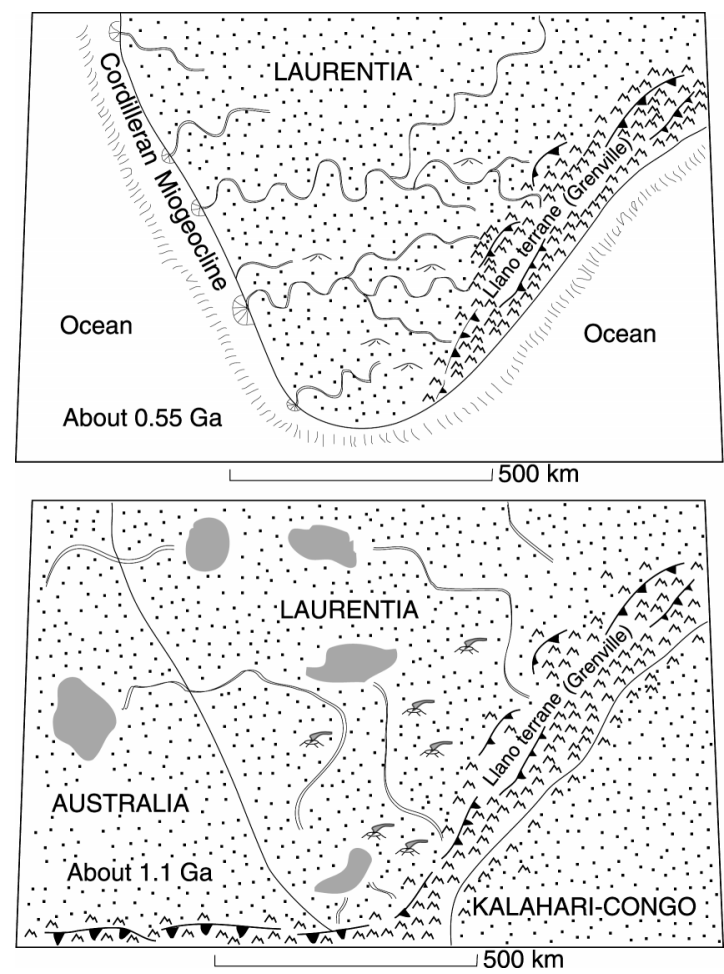

Figure 7. Diagrams showing provenance of detrital zircons in Laurentia at $1.1 \mathrm{Ga}$ and 0.55 Ga. Curved lines indicate rivers. Coarsely stippled areas are land. Gray areas are sedimentary basins. Active volcanic centers are shown with ash plume, inactive volcanic centers without plume. Peak-like symbols indicate mountainous areas. Line with barbs is thrust fault; barbs are on upper plate.

brian arenites in the western United States and northern Mexico is apparently small, it may have been underestimated.

Nevertheless, the sparseness of volcanic detritus in the Proterozoic and Cambrian arenites described here argues against a silicic volcanic source for the $1.1 \mathrm{Ga}$ zircon. However, it is difficult to explain the dominance of $1.1 \mathrm{Ga}$ detrital zircons in the arenites without a large igneous source of a specific age. Such sources are not known to crop out; either they are hidden or are now represented only by the buried roots of such silicic igneous systems. We favor the latter idea. The scarcity of volcanic material in the arenites may be explained by reworking and attrition of less resistant volcanic detritus.

\section{Sources in Rifted Continental Blocks}

An unknown amount of the zircon in the Mesoproterozoic and Cambrian arenites of the western United States and northern Mexico may have been derived from continental blocks that have been rifted away from North America (Fig. 7). In the reconstruction of Hoffman (1991) and Dalziel (1991, 1992), built in part on the SWEAT hypothesis of Moores (1991) and modified by $\mathrm{Li}$ el at (1995), Karlstrom et al. (1999), and Burrett and Berry (2000), ancestral North America (Laurentia) was an interior part of the much larger hypothetical supercontinent of Rodinia during Neoproterozoic time. The Hoffman (1991) and Dalziel (1991, 1992) reconstructions show the Antarctic craton and Kalahari craton of southern Africa adjacent to what is now Mexico. Such an assembly is supported by the presence in the Kalahari craton of 1.1 Ga dolerites similar to the $1.1 \mathrm{Ga}$ diabase in the western United States (Hanson et al., 1998). In the Karlstrom et al. (1999) and Burrett and Berry (2000) reconstruction, Australia lies adjacent to Mexico to the west, in present coordinates. Although not specified by Karlstrom el al (1999) or Burrett and Berry (2000), the Kalahari and Congo cratons possibly lay to the southeast. In an alternate models, Sears and Price (2000) proposed that northeast Siberia was adjacent to western Laurentia, and $\mathrm{Li}$ el al (1995) proposed that the South China craton lay between Australia and what is now northwestern North America. In these assemblies, some of our sample sites, particularly those in Sonora, Mexico, originally would have been close to either the Antarctic, Australia, Kalahari, or Congo cratons (Fig. 7), which thus would have been possible source areas for the zircons. In particular, the Mesoproterozoic and/or Neoproterozoic El Alamo Formation, from which one of our samples was collected, appears to be old enough to have been deposited within the supercontinent of Rodinia. Paleocurrent directions in the El Alamo Formation are somewhat variable, but indicate generally north flowing paleocurrents. Such paleocurrents are consistent with derivation of detrital material from the south, perhaps from the fringe of what later became Laurentia, or from the Antarctic, Australian, Kalahari, or Congo cratons.

The most likely zircons in our samples to have had a source in a rifted continental block are $1.576 \mathrm{Ga}$ and $1.578 \mathrm{Ga}$ detrital zircons in the Sahuaripa Member. Possibly related detrital zircons are a $1.619 \mathrm{Ga}$ zircon in the Sahuaripa Member, a $1.612 \mathrm{Ga}$ zircon in the El Alamo Formation, 1.605 to 1.619 Ga zircons in the Bolsa Quartzite, and a $1.600 \mathrm{Ga}$ zircon in the Tapeats Sandstone. All of these 1.619 to $1.576 \mathrm{Ga}$ zircons are in Sonora, except for the one in the Tapeats Sandstone.

Zircons of 1.619 to $1.576 \mathrm{Ga}$ are common in the Gawler craton (Fanning et al., 1988) and North Queensland (Blewett et al., 1998) of eastern Australia, and are known in western North America only in the Laclede augen gneiss in the Priest River complex astride the Canadian-U.S. boundary. The Laclede augen gneiss contains 1.576 to $1.577 \mathrm{Ga}$ zircons (Evans and Fischer, 1986; Doughty et al., 1997). Doughty el al. (1997) considered the Priest River complex to have been a piece of eastern Australia before it was stranded on Laurentia during rifting of the supercontinent of Rodinia in the Neoproterozoic; if that were so, the presence of 1.576 to $1.577 \mathrm{Ga}$ zircons in the Priest River complex does not argue against an exotic source for the 1.619 to 1.576 Ga zircons described here. Ross et al. (1992) and Ross and Villeneuve (1999) have proposed that 1.590 to $1.600 \mathrm{Ga}$ detrital zircons in the Belt Supergroup had a source in the Gawler craton, and Blewett et al. (1998) has proposed a North Queensland source for these detrital zircons in the Belt Supergroup. Barth et al. (2000a) also proposed an exotic source for upper Proterozoic strata in the San Bernardino Mountains of California.

In eastern Australia, some detrital zircon populations from Neoproterozoic and Cambrian arenites (Ireland et al., 1998) show a poorly defined similarity to those in the western United States and northern Mexico, particularly if 
post-Rodinian zircons of about $0.5 \mathrm{Ga}$ are excluded. Some arenites from Australia show abundant detrital zircons in the range from 2.1 to $1.6 \mathrm{Ga}$, a range that corresponds partly to the 1.90 to $1.62 \mathrm{Ga}$ range of abundant zircons in the United States. Zircons in the range of 1.619 to $1.576 \mathrm{Ga}$ are present in the Sahuaripa Member, El Alamo Formation, Bolsa Quartzite, and Tapeats Sandstone, and zircons of this age are also present in some of the Australian units. Detrital zircons in the western United States, northern Mexico, and Australia are also similar in having abundant zircons of about $1.0 \mathrm{Ga}$. However, 1.45 to $1.40 \mathrm{Ga}$ zircons are sparse in the Australian arenites whereas they are common in arenites of the western United States and northern Mexico.

Detrital zircon ages from Antarctica (Walker, 1996) do not support the idea that the Antarctic craton was close to the western United States and northern Mexico, as proposed in the Rodinian reconstruction. Detrital zircons from Antarctica are dominated by 1.2 to $1.0 \mathrm{Ga}$ zircons, but in places include 2.3 to $2.2 \mathrm{Ga}$ and 0.7 and $0.65 \mathrm{Ga}$ zircons (Walker, 1996). The 1.2 to $1.0 \mathrm{Ga}$ zircons match ages of zircons in the western United States, but the 2.3 to $2.2 \mathrm{Ga}$ zircons are in the void of zircons described here. In comparison with zircons from Antarctica, only three ca. $0.700 \mathrm{Ga}$ zircons were found in this study (Wood Canyon Formation and Rancho Curiel unit), and none of $0.65 \mathrm{Ga}$.

Detrital zircons in the Mayamkan Formation of Siberia (Rainbird et al., 1998; Sears and Price, 2000) range from 1.500 to 1.105 $\mathrm{Ga}$. The oldest of these zircons is younger than the ca. $1.560 \mathrm{Ga}$ zircons of the Sahuaripa formation, suggesting that the Siberian and Sonoran arenites may not have had the same source, and thus that they were not juxtaposed before the breakup of Rodinia.

After the fragmentation of Rodinia and the rifting away of the Antarctic, Australian, Kalahari, Congo, or Siberian cratons in Neoproterozoic time, direct transport of detrital material from these cratons to Laurentia was impossible. Nevertheless, detrital material from these cratons may have been left on North America in basins that formed prior to the breakup of Rodinia. If that were so, such basinal deposits possibly could have been recycled into the Neoproterozoic and Cambrian arenites of the Cordilleran miogeocline.

\section{SUMMARY AND CONCLUSIONS}

Multiple sources of zircons are indicated by our study. Zircons older than 3.0 Ga are considered to have been derived from the Wyoming province in the northern United States and continuations in Canada. Zircons ranging in age from 1.9 to $1.6 \mathrm{Ga}$ have likely sources in the Yavapai, Mazatzal, and Mojave provinces in the southwest United States. Zircons ranging from 1.45 to $1.40 \mathrm{Ga}$ almost certainly were derived from widespread granitoids of this age in the southwest United States. Zircons ranging from 1.2 to $1.0 \mathrm{Ga}$ may have been derived in part from silicic volcanic fields and in part from the Grenville province (Fig. 6). These multiple sources suggest that the provenance of the arenites was an area of mixing of detritus from various areas, perhaps by fluvial and eolian processes. However, the mixing was not complete, and different units tapped somewhat different provenance areas to account for variation in the ages of zircons between samples. Movement of zircons from distant sources may have occurred over a protracted period of time in which the zircons were transported, deposited, eroded, and transported again in several cycles.

Most of the zircons studied could have been derived from what is now North America, and most could be from the south and southwest United States. The only zircons that may indicate an exotic source are a few 1.619 to $1.576 \mathrm{Ga}$ detrital zircons that cannot be easily related to North American sources, but that correspond closely to terranes of this age in Australia. Ross et al. (1992) and Barth et al. (2000a) have suggested such a source in Australia on the basis of detrital zircon studies elsewhere in the western United States.

Our two Mesoproterozoic samples (Dripping Spring and Troy quartzites) are interpreted to have been derived mainly from large silicic volcanic fields that may have formed and been eroded away during, or before, the early phase of the Grenville orogeny and the consolidation of Rodinia. During and after the consolidation of Rodinia, detritus derived from the Grenville orogen was mixed with cratonal detritus and perhaps $1.11 \mathrm{Ga}$ detritus shed from silicic volcanic fields in the southwest. Large amounts of eolian and fluvial sand accumulated on the surface and in epicontinental basins of Rodinia. After the fragmentation of Rodinia, this sand was transported off the craton and contributed to the sand-rich Neoproterozoic and Cambrian part of the Cordilleran miogeocline.

\section{ACKNOWLEDGMENTS}

We thank David L. Parkinson, Gerald M. Ross, and Nancy Riggs for their helpful reviews of the manuscript.

\section{REFERENCES CITED}

Adams, D.C., and Keller, G.R., 1994, Possible extension of the Midcontinent rift in west Texas and eastern New Mexico: Canadian Journal of Earth Sciences, v. 31, p. 709-720.
Anderson, J.L., 1989, Proterozoic anorogenic granites of the southwestern United States, in Jenny, J.P., and Reynolds, S.J., Geologic evolution of Arizona: Tucson, Arizona Geological Society Digest, v. 17, p. 211-238.

Anderson, T.H., Eells, J., and Silver, L.T., 1979, Geology of the Precambrian and Paleozoic rocks, Caborca-Bamori region, in Anderson, T.H., and Roldan-Quintana, J., eds., Geology of northern Sonora: Pittsburgh, Pennsylvania, and Hermosillo, Mexico, University of Pittsburgh and Instituto de Geología, Guidebook for Field Trip 27, Geological Society of America Annual Meeting, p. 1-22.

Barth, A.P., Wooden, J.L., Tosdal, R.M., Morrison, Jean, Dawson, D.L., and Hernley, B.M., 1995, Origin of gneisses in the aureole of the San Gabriel Anorthosite complex and implications for the Proterozoic crustal evolution of southern California: Tectonics, v. 14, p. 736-752.

Barth, A.P., Coleman, D.S., Wooden, J.L., and Stewart, J.H., 2000a, Disassembling California: Rifting and initiation of the Cordilleran miogeocline, San Bernardino Mountains, California: Geological Society of America Abstracts with Programs, v. 32, no. 6, p. A-3.

Barth, A.P., Wooden, J.L., Coleman, D.S., and Fanning, C.M., 2000b, Geochronology of the Proterozoic basement of southwesternmost North America, and the origin and evolution of the Mojave crustal province: Tectonics, v. 19, p. 616-629.

Barth, A.P., Wooden, J.L., and Coleman, D.S., 2001, SHRIMP-RG U-Pb zircon geochronology of Mesoproterozoic metamorphism and plutonism in the southwesternmost United States: Journal of Geology, v. 109 , p. 319-327.

Blewett, R.S., Black, L.P., Sun, S-s, Knutson, J., Hutton, L.J., and Bain, J.H.C., 1998, U-Pb zircon and Sm-Nd geochronology of the Mesoproterozoic of North Queensland: Implications for a Rodinian connection with the Belt Supergroup of North America: Precambrian Research, v. 89, p. 101-127.

Burrett, C, and Berry, R., 2000, Proterozoic Australia-western United States (AUSWUS) fit between Laurentia and Australia: Geology, v. 28, p. 103-106.

Campa-Uranga, M., 1997, Paleozoic suspect terranes in southeastern North America and Grenvillian protocontinents, in Bradshaw, J., and Weaver, S., eds., Terrane dynamics: Christchurch, New Zealand, University of Canterbury, p. 30-33.

Christie-Blick, N., and Levy, M., editors, 1989, Late Proterozoic and Cambrian tectonics, sedimentation, and record of metazoan radiation in the western United States, in International Geological Congress, 28th, Field Trip Guidebook T331: Washington, D.C., American Geophysical Union, 111 p.

Cook, T.D., and Bally, A.W., editors, 1975, Stratigraphic atlas of North and Central America, prepared by the exploration department of Shell Oil Company, Houston, Texas: Princeton, New Jersey, Princeton University Press, $271 \mathrm{p}$.

Corsetti, F.A., Stewart, J.H., and Hagadorn, J.W., 2001, Neoproterozoic diamictite-cap carbonate succession from eastern Sonora, Mexico: Geological Society of America Abstracts with Programs, v. 33, no. 5, p. A-21.

Dalziel, I.W.D., 1991, Pacific margins of Laurentia and East Antarctica-Australia as a conjugate rift pair: Evidence and implications for an Eocambrian supercontinent: Geology, v. 19, p. 598-601.

Dalziel, I.W.D., 1992, On the organization of American plates in the Neoproterozoic and the breakout of Laurentia: GSA Today, v. 2, p. 237-241.

Dodson, M.H., Compston, W., Williams, I.S., and Wilson, J.F., 1988, A search for ancient detrital zircons in Zimbabwean sediments: Geological Society of London Journal, v. 145, p. 977-983.

Doughty, P.T., Price, R.A., and Parrish, R.R., 1997, Geology and U-Pb geochronology of Archean basement and Proterozoic cover of the Priest River complex, northwestern United States, and their implications for Cordilleran structure and Precambrian continental reconstructions: Canadian Journal of Earth Sciences, v. 35 , p. 39-54.

Evans, K.V., and Clemens, R.E., 1988, Cambrian-Ordovician (500 Ma) alkalic plutonism in southwestern New Mexico: U-Th-Pb isotopic data from the Florida Mountains: American Journal of Science, v. 288, p. 735-755. 
Evans, K.V., and Fischer, L.B., 1986, U-Th-Pb geochronology of two augen gneiss terranes, Idaho: New data and tectonic implications: Canadian Journal of Earth Sciences, v. 23, p. 1919-1927.

Evans, K.V., Lund, K., Aleinikoff, J.N., and Fanning, C.M., 1997, SHRIMP U-Pb age of Late Proterozoic volcanism in central Idaho: Geological Society of America Abstracts with Programs, v. 29, no. 6, p. A-196.

Fanning, C.M., Flint, R.B., Parker, A.J., Ludwig, K.R., and Blissett, A.H., 1988, Refined Proterozoic evolution of the Gawler Craton, Southern Australia, through U-Pb zircon geochronology: Precambrian Research, v. 40/ 41 , p. $363-386$.

Farmer, G.L., and Ball, T.T., 1997, Sources of Middle Proterozoic to Early Cambrian siliciclastic sedimentary rocks in the Great Basin: A Nd study: Geological Society of America Bulletin, v. 109, p. 1193-1205.

Gastil, R.G., 1954, Late Precambrian volcanism in southeastern Arizona: American Journal of Science, v. 252, p. $436-440$.

Gehrels, G.E., and Dickinson, W.R., 1995, Detrital zircon provenance of Cambrian to Triassic miogeoclinal and eugeoclinal strata in Nevada: American Journal of Science, v. 295 , p. $18-48$.

Gehrels, G.E., and Stewart, J.H., 1998, Detrital zircon U$\mathrm{Pb}$ geochronology of Cambrian to Triassic miogeoclinal and eugeoclinal strata of Sonora, Mexico: Journal of Geophysical Research, v. 103, p. 2471-2487.

Gehrels, G.E., Dickinson, W.R., Ross, G.M., Stewart, J.H., and Howell, D.G., 1995, Detrital zircon reference for Cambrian to Triassic miogeoclinal strata of western North America: Geology, v. 23, p. 831-834.

Gehrels, G.E., Dickinson, W.R., Riley, B.C.D., Finney, S.C., and Smith, M.T., 2000, Detrital zircon geochronology of the Roberts Mountains allochthon, Nevada, in Soreghan, M.J., and Gehrels, G.E., eds., Paleozoic and Triassic paleogeography and tectonics of western Nevada and northern California: Geological Society of America Special Paper 347, p. 19-42.

Gleason, J.D., Gehrels, G.E., and Finney, S.C., 2001, Tectonic recycling in the Paleozoic Ouachita Assemblage from U-Pb detrital zircon studies: Eos, Transactions: American Geophysical Union, supplement, v. 82, no. 20, p. S435.

Grasse, S.W., Gehrels, G.E., Lahren, M.M., Schweickert, R.A., and Barth, A.P., 2001, U-Pb geochronology of detrital zircons from the Snow Lake pendant, central Sierra Nevada, California-Implications for Late Jurassic-Early Cretaceous dextral strike-slip faulting: Geology, v. 29, p. 307-310.

Gross, E.L., Stewart, J.H., and Gehrels, G.E., 2000, Detrital zircon geochronology of Neoproterozoic to Middle Cambrian miogeoclinal and platform strata: Northwest Sonora, Mexico: Geofísica International, v. 39, p. 295-308.

Hanson, R.E., Martin, M.W., Bowring, S.A., and Munyanyiwa, H., 1998, U-Pb zircon age for the Umkondo dolerites, eastern Zimbabwe: Geology, v. 26, p. $1143-1146$.

Heaman, L.M., and Grotzinger, J.P., 1992, 1.08 Ga diabase sills in the Pahrump Group, California: Implications for development of the Cordilleran miogeocline: Geology, v. 20, p. 637-640.

Hoffman, P.F., 1989, Precambrian geology and tectonic history of North America, in Bally, A.W., and Palmer, A.R., eds., The geology of North America-An overview: Boulder, Colorado, Geological Society of America, Geology of North America, v. A., p. 447-512.

Hoffman, P.F., 1991, Did the breakout of Laurentia turn Gondwanaland inside-out?: Science, v. 252, p. 1409-1412.

Houston, R.S., Erslev, E.A., Frost, C.D., Karlstrom, K.E., Page, N.J., Zientek, M.L., Reed, J.C., Jr., Snyder, G.L., Worl, R.G., Bryant, B., Reynolds, M.W., and Peterman, Z.E., 1993, The Wyoming province, in Reed, J.C., Jr., et al., eds., Precambrian: Conterminous U.S.: Boulder, Colorado, Geological Society of America, Geology of North America, v. C.2, p. 121-170.

Howard, K.A., 1991, Intrusion of horizontal dikes: Tectonic significance of Middle Proterozoic diabase sheets widespread in the upper crust of the southwestern
United States: Journal of Geophysical Research, v. 96, p. 12461-12478.

Ireland, T.R., Flöttman, T, Fanning, C.M., Gibson, G.M., and Preiss, W.V., 1998, Development of the early Paleozoic Pacific margin of Gondwana from detrital-zircon ages across the Delamerian orogen: Geology, v. 26, p. 243-246.

Jones, A.E., 1997, Geology of the Delvada Spring quadrangle, Humboldt County, Nevada: Nevada Bureau of Mines and Geology Field Studies Map 13.

Karlstrom, K.E., Williams, M.L., McLelland, J., Geissman, J.W., and Åhäll, Karl-Inge, 1999, Refining Rodinia: Geologic evidence for the Australia-western U.S. connection in the Proterozoic: GSA Today, v. 9, no. 10, p. 1-7.

Karlstrom, K.E., Bowring, S.A., Dehler, C.M., Knoll, A.H., Porter, S.M., Marais, D.J.D., Weil, A.B., Sharp, Z.D., Geissman, J.W., Elrick, M.B., Timmons, J.M., Crossey, L.J., and Davidek, K.L., 2000, Chuar Group of the Grand Canyon: Record of breakup of Rodinia, associated change in global carbon cycle, and ecosystem expansion by 740 Ma: Geology, v. 28, p. 619-622.

Larson, E.E., Patterson, P.E., and Mutschler, F.E., 1994, Lithology, chemistry, age, and origin of the Proterozoic Cardenas Basalt, Grand Canyon, Arizona: Precambrian Research, v. 65 , p. $255-276$.

LeCheminant, A.N., and Heaman, L.M., 1989, Mackenzie igneous events, Canada: Middle Proterozoic hotspot magmatism associated with ocean opening: Earth and Planetary Science Letters, v. 96, p. 38-48.

Li, Zheng-Xiang, Zhang, L., and Christopher, M.A., 1995, South China in Rodinia: Part of the missing link between Australia-Antarctica and Laurentia?: Geology, v. 23 , p. $407-410$.

Link, P.K, Christie-Blick, N., Devlin, W.J., Elston, D.P., Hordyski, R.J., Levy, M., Miller, J.M.G., Pearson, R.C., Rave, A., Stewart, J.H., Winston, D., Wright, L.A., and Wrucke, C.T., 1993, Middle and Late Proterozoic stratified rocks of the western U.S. Cordillera, Colorado Plateau, and Basin and Range province, in Reed, J.C., Jr., et al., eds., Precambrian: Conterminous U.S.: Boulder, Colorado, Geological Society of America, Geology of North America, v. C-2, p. 463-595.

Lobo, C.F., and Osborne, R.H., 1976, Petrology of late Precambrian-Cambrian quartzose sandstones in the eastern Mojave Desert, southeastern California: Journal of Sedimentary Petrology, v. 46, p. 829-846.

Loring, A.K., and Armstrong, G.G., 1980, Cambrian-Ordovician syenites of New Mexico, part of a regional alkalic intrusive episode: Geology, v. 8, p. 344-348.

McConnell, D.A., and Gilbert, M.C., 1990, Cambrian extensional tectonics and magmatism within the Southern Oklahoma aulacogen: Tectonophysics, v. 174, p. 147-157.

Middleton, L.T., 1989, Cambrian and Ordovician depositional systems in Arizona, in Jenny, J.P., and Reynolds, S.J., eds., Geologic evolution of Arizona: Tucson, Arizona Geological Society Digest 17, p. 273-286.

Moores, E.M., 1991, Southwest U.S.-East Antarctic (SWEAT) connection: A hypothesis: Geology, v. 19, p. $425-428$.

Mosher, S., 1998, Tectonic evolution of the southern Laurentian Grenville orogenic belt: Geological Society of America Bulletin, v. 110, p. 1357-1375.

Nutt, C.J., 1981, A model of uranium mineralization in the Dripping Spring Quartzite, Gila County, Arizona: U.S. Geological Survey Open-File Report 81-524, 53 p.

Patchett, PJ., Ross, G.M., and Gleason, J.D., 1999, Continental drainage in North America during the Phanerozoic from Nd isotopes: Science, v. 283, p. 671-673.

Powell, C.McA., Preiss, W.V., Gatehouse, C.G., Krapez, B, and Li, Z.X., 1994, South Australian record of a Rodinian epicontinental basin and its mid-Neoproterozoic breakup ( $\sim 700 \mathrm{Ma})$ to form the Palaeo-Pacific Ocean: Tectonophysics, v. 237, p. 113-140.

Powell, R.E., 1993, Balanced palinspastic reconstruction of pre-late Cenozoic paleogeology, southern California; geologic and kinematic constraints on evolution of the San Andreas fault system, in Powell, R.E., et al., eds., The San Andreas fault system; displacement, palinspastic reconstruction, and geologic evolution: Geological Society of America Memoir 178, p. 1-100

Preiss, W.V., 1993, Neoproterozoic, in Drexel, J.F., et al., eds., The geology South Australia, Volume 1, The Precambrian: South Australia Geological Survey Bulletin 54, p. 171-202.

Rainbird, R.H., Heaman, L.M., and Young, G., 1992, Sampling Laurentia: Detrital zircon geochronology offers evidence for an extensive Neoproterozoic river system originating from the Grenville orogen: Geology, v. 20, p. 351-354.

Rainbird, R.H., Stern, R.A., Khudoley, A.K., Kropachev, A.P., Heaman, L.M., and Sukhorukov, V.I., 1998, U $\mathrm{Pb}$ geochronology of Riphean sandstone and gabbro from southeast Siberia and its bearing on the Laurentia-Siberia connection: Earth and Planetary Science Letters, v. 164, p. 409-420.

Rodrígues-Castañeda, J.L., 1994, Geología del área el Teguachi, Estado de Sonora, México: Revista Mexican de Ciencias Geológicas, v. 11, no. 1, p. 11-28.

Ross, G.M., 1991, Tectonic setting of the Windermere Supergroup revisited: Geology, v. 19, p. 1125-1128.

Ross, G.M., and Villeneuve, M.E., 1999, The Belt basin: Provenance insights offer tectonic hindsights: Geolog ical Society of America Abstracts with Programs, v. 31, no. 7, p. A-300.

Ross, G.M., Parrish, R.R., and Winston, D., 1992, Provenance and $\mathrm{U}-\mathrm{Pb}$ geochronology of the Mesoproterozoic Belt Supergroup (northwestern United States): Implications for age of deposition and pre-Panthalass plate reconstructions: Earth and Planetary Science Letters, v. 113, p. 57-76.

Sastri, L.L., Chamberlain, K.R., and Bowring, S.A., 1991, Inherited zircon from ca. 1.1 Ga mafic dikes, NW Arizona: Geological Society of America Abstracts with Programs, v. 23 , no. 4 , p. 93

Sears, J.W., and Price, R.A., 2000, New look at the Siberian connection: No SWEAT: Geology: v. 28, p. 423-430.

Seeland, D.A., 1968, Paleocurrents of the late Precambrian to Early Ordovician (basal Sauk) transgressive clastics of the western and northern United States [Ph.D. thesis]: Salt Lake City, University of Utah, 276 p.

Stewart, J.H., 1970, Upper Precambrian and Lower Cambrian strata in the southern Great Basin, California and Nevada: U.S. Geological Survey Professional Paper 620, 206 p.

Stewart, J.H., 1991, Latest Proterozoic and Cambrian rocks of the western United States-An overview, in Cooper, J.D., and Stevens, C.H., eds., Paleozoic paleogeography of the western United States-II, volume 1: Los Angeles, Pacific Section, Society of Economic Paleontologists and Mineralogists, book 67, p. 13-38.

Stewart, J.H., and Amaya-Martínez, Ricardo, 1999, New appraisal of Neoproterozoic and Cambrian strata in Sonora, Mexico in Calmas, Thierry, and Pérez-Segura, E. eds., Cuarta reunion sobre la geología del noroeste de Mexico y areas adyacentes, Libro de Resumenes: Hermosillo, Mexico, Instituto de Geología, p. 129-130.

Van Schmus, W.R., Bickford, M.E., Anderson, J.L., Bender, E.E., Anderson, R.R., Bauer, P.W., Robertson, J.M., Bowring, S.A., Condie, K.C., Denison, R.E., Gilbert, M.C., Grambling, J.A., Mawer, C.K., Shearer, C.K., Hinze, W.J., Karlstrom, K.E., Kisvarsanyi, E.B., Li diak, E.G., Reed, J.C., Jr., Sims, P.K., Tweto, O., Silver, L.T., Treves, S.B., Williams, M.L., and Wooden, J.L., 1993, Transcontinental Proterozoic provinces, in Reed, J.C., Jr., et al., eds., Precambrian: Conterminous U.S.: Boulder, Colorado, Geological Society of America, Geology of North America, v. C-2, p. 171-334.

Walker, N.W., 1996, Testing the "Sweat" hypothesis: Ages of detrital zircons in upper Neoproterozoic siliciclastic rocks from east Antarctica and southwest Laurentia: Geological Society of America Abstracts with Programs v. 28, no. 5, p. 121

Wrucke, C.T., 1989, The Middle Proterozoic Apache Group, Troy Quartzite, and associated diabase of Arizona, in Jenny, J.P., and Reynolds, S.J., eds., Geolog ic evolution of Arizona: Tucson, Arizona Geological Society Digest 17 , p. 239-258.

Young, G.M., 1979, Correlation of middle and upper Proterozoic strata of the northern rim of the North American craton: Royal Society of Edinburgh Transactions, v. 70, p. $323-336$.

Manuscript Received by the Society March 31, 2000 ReVised Manuscript Received January 9, 2001 MANUSCRIPT ACCEPTED MARCH 15, 2001

Printed in the USA 